\title{
COVID-19 Pandemisi Döneminde Riskli Gebe İzlemi ve Yönetimi
}

\section{Follow up and Management of High Risk Pregnancies in COVID-19 Pandemic}

\author{
Atakan TANAÇAN \\ (1) orcid id:0000-0001-8209-8248 \\ Seyit Ahmet EROL \\ (1) orcid id:0000-0002-2494-4896 \\ Aykan YÜCEL \\ (1) orcid id:0000-0002-5888-692X
}

1 T.C. Sağlık Bakanlığı Ankara Șehir Hastanesi Perinatoloji Kliniği, Ankara, Türkiye

2 T.C. Sağlık Bilimleri Üniversitesi, İstanbul, Türkiye

\section{öz}

Koronavirüs hastalığı 2019 (COVID-19) tüm dünyayı etkisi altına almış olan bir pandemidir. İlk ortaya çıktığı 2019 yılı sonundan günümüze kadar çok hızı bir yayılım göstermiş, ülkelerdeki sağlık sistemleri üzerinde ciddi bir yük oluşturmuştur. Öte yandan enfekte ettiği hastaların \%15'ine yakınında pnömoni tablosu yaratmış, \%5'ine yakınında da mortal olarak seyretmiştir. Virüsün ana bulaş yolu enfekte solunum damlacıklarının göz, burun ve ağızdaki müköz membranlar ile temasıdır. Daha çok komorbit hastalı̆ı mevcut olan ileri yaş hastalarda kötü prognoz göstermekle beraber genç hastalarda da ağır klinik tablolara yol açabilmekte ve daha önemlisi bu hastalar üzerinden risk grubundaki bireylere bulaş göstererek ciddi bir toplum sağlığı sorunu oluşturabilmektedir. Şu an için hastalığın aktif bir tedavisi ve aşısı mevcut değildir. Enfeksiyonla mücadelede en önemli adım bulaşı önlemek olarak görünmektedir. Hidroksiklorokin, azitromisin, oseltamivir, favipravir ve lopinavir/ritonavir gibi ilaçlar üzerinde hastalığın prognozu için olumlu olabilecekleri yönünde çalışmalar mevcuttur. Bilindiği üzere gebelik pek çok immünolojik adaptif değişikliği beraberinde getirmektedir ve gebe popülasyon enfeksiyon hastalıklarına karşı daha duyarlıdır. Bu yüzden hastalığın gebe hastalardaki gidişatı, obstetrik komplikasyonlarla ilişkisi, güvenli tedavi yaklaşımları, prenatal takip ve intrapartum yönetim gibi konular üzerinde tartışmalar devam etmektedir. Virüsün gebelerde genel popülasyon ile benzer semptomlara yol açtığı düşünülmektedir. Çoğunlukla soğuk algınlığı ve grip benzeri bir klinik tablo mevcuttur. Buna karşın bazı çalışmalarda fetal distres ve preterm eylem riskini arttırabileceği gösterilmiştir. Yine bu vakalarda artmış sezaryen oranları dikkat çekmektedir. Vertikal geçiş ile ilgili net bilgi olmamakla beraber literatürde şüpheli vakalar mevcuttur. Sadece 30 hafta 3 günlük gebeliği olan bir vakada maternal ölüm bildirilmiştir. Gebe hastaların tedavisinde hidroksiklorokin ve lopinavir/ritonavir kombinasyonu tercih edilmektedir. Gebe popülasyonu korumak amacı ile prenatal takip sayısının ve muayene süresinin azaltılması önerilmektedir. Ayrıca hem sağlık personeli hem de muayene olan gebeler bulaş riskini azaltmak için gerekli kişisel önlemlerini almalıdır. Yine sağık kuruluşları personelini ve diğer hasta popülasyonu korumak amacı ile uygun yönetim şeması oluşturmalıdır.

Şüpheli vakaların yönetimi multidisipliner bir ekip tarafından sağlanmalıdır. Doğum yapacak hastalarda maternal sağlığın yanında sağık personelinin de korunması hedeflenmeli, hastaneler bu hastaların doğumu için negatif basınçlı izole özel alanlar belirlemelidir. Kişisel koruyucu ekipman kullanımı konusunda gerekli bilgilendirme yapıımalı, bu hastaların yönetiminde belirlenmiş olan kurallara titizlikle uyulmalıdır. Postpartum dönemde neonatal bulaş riski ile beraber emzirmenin önemi de göz önünde bulundurulmalı, gerekli önlemler alınarak anne-bebek bağlanması sağlanmalıdır. Bu derlemeyi yazmamızdaki amaç COVID-19 enfeksiyonu olan gebelerin sonuçlarını uluslararası literatür bazında gözden geçirmek ve bahsi geçen gebelerin obstetrik olarak yönetiminde klinisyenlere katkıda bulunmaktır.

Anahtar kelimeler: COVID-19, gebelik, prenatal takip, intrapartum yönetim, tedavi, prognoz 


\section{ABSTRACT}

Coronavirus disease 2019 (COVID-19) is a pandemic that has influenced the whole world. It has spread rapidly since the first time it appeared in 2019 until today, creating a serious burden on the health systems in the countries. On the other hand, it has caused pneumonia in about $15 \%$ of the patients it infected with an approximate mortality rate of $5 \%$. The main transmission route of the virus is the contact of infected respiratory droplets with the mucous membranes in the eyes, nose and mouth. Although it shows poor prognosis in older patients with more comorbid diseases, it can lead to severe clinical pictures in young patients and, more importantly, it can cause a serious public health problem by infecting individuals at risk through these patients. There is currently no effective treatment and vaccine for the disease. The most important step in the fight against infection seems to prevent transmission. There are studies in the literature reporting favorable outcomes with drugs like hydroxychloroquine, azithromycin, oseltamivir, favipravir and lopinavir I ritonavir. Pregnancy goes together with many immunological adaptive changes and pregnant population is more susceptible to infectious diseases. Therefore, discussions continue on issues such as the course of the disease in pregnant patients, its relation with obstetric complications, safe treatment approaches, prenatal follow-up and intrapartum management. The virus is thought to cause symptoms similar to the general population in pregnant women. Generally, flu-like clinical symptoms are observed. However, some studies have indicated increased risk for fetal distress and preterm labor in pregnancies complicated by COVID-19. Increased cesarean rates are also remarkable. Although there is no clear information about vertical transition, there are suspicious cases in the literature. Maternal death has been reported in only one case with a 30-week and 3-day pregnancy. Hydroxychloroquine and lopinavir / ritonavir combination is preferred in the treatment of pregnant patients. In order to protect the pregnant population, it is recommended to reduce the number of prenatal follow-up and the duration of the examination. In addition, both healthcare professionals and pregnant women who are examined should take the necessary personal precautions to reduce the risk of transmission. Again, health institutions should establish an appropriate management scheme to protect their staff and other patient populations. Management of suspicious cases should be ensured by a multidisciplinary team. In addition to maternal health, the protection of health personnel should be targeted in hospitals, and hospitals should designate isolated areas with negative pressure for the birth of these patients. Necessary information should be provided about the use of personal protective equipment, and the rules determined in the management of these patients should be followed carefully. In the postpartum period, the importance of breastfeeding should be taken into consideration along with the risk of neonatal transmission, and mother-baby attachment should be ensured by taking the necessary precautions. The purpose of this review is to review the results of pregnant women with COVID-19 infection on the basis of international literature and contribute to clinicians in the obstetric management of these pregnant women.

Keywords: COVID-19, pregnancy, prenatal follow up, intrapartum management, treatment, prognosis

\section{GíRiş}

Koronavirüsler hem insanlarda hem de hayvanlarda enfeksiyon yapma potansiyeline sahip patojenlerdir. Çin'in Hubei Eyaleti'nin Wuhan kentinde 2019 yılının sonunda baş gösteren yeni tip bir koronavirüs çok hızlı bir yayılım göstermiş ve kısa süre içerisinde çok sayıda insanı enfekte ederek bir epidemi başlatmıştır. Bu yeni tip korona virüsü Dünya Sağlık Örgütü (WHO) tarafından koronavirüs hastalığı 2019 (COVID-19) olarak adlandırımış ve 11.03.2020 tarihinde pandemi olarak kabul edilmiştir (1). Yeni tip Korona virus (2019-nCoV), Severe Acute Respiratory Syndrome Coronavirus (SAR$\mathrm{Sr}-\mathrm{CoV}$ ) ve Middle East Respiratory Syndrome Coronavirus (MERSr-CoV) gibi beta Koronavirus ailesinin bir üyesidir. Buna karşın bu yeni virüs genetik olarak daha çok yarasaları enfekte eden bat-SL-CoVZ45 virüsü ile benzerlik göstermektedir (\%85) (2). Virüs UV ışınlarına ve ısıya duyarlıdır. 56 oC ısının 30 dakika süreyle uygulanması, dietil eter, $\% 75$ etanol, kloridli dezenfektanlar ve $\mathrm{H} 2 \mathrm{O} 2$ ile maruziyet sonrası virüs etkin bir biçimde deaktive edilebilmektedir (2). 2019-nCoV, tek zincirli, pozitif polariteli, zarflı bir RNA virüsüdür. Pozitif polariteli olduğu için RNA'ya bağımlı RNA polimeraz enzimi içermez, ancak genomunda bu enzimi kodlar. Korona virüs ailesinin diğer üyeleri gibi yüzeyinde çubuksu uzantıları mevcuttur (3). Virüsün hücre içine girmek için Angiotensin-Converting Enzyme 2 (ACE2) reseptörünü kullandığı bulunmuştur (4).

Virüsün ana bulaş yolu enfekte solunum damlacıklarının göz, burun ve ağızdaki müköz membranlar ile temasıdır. Damlacıkların en fazla 2 m mesafeye kadar yayılım gösterebildiği ve havada asılı kalamadığı düşünülmektedir. Bunun yanında enfekte solunum sekresyonları ile temas etmiş materyallerin ortak kullanımı da virüs açısından bir bulaş yolu oluşturmaktadır (5). SARS-CoV-2 RNA'sı ayrıca kan ve gayta örneklerinde de gösterilmiştir; fakat bu materyaller ile bulaş konusunda yeterli veri mevcut değildir $(6,7)$. Hastalı̆ıın inkübasyon periyodu ortalama 5 gündür (2-14 gün) (8). Bazı vakalarda asemptomatik olarak geçirilebilmekle beraber, çoğunlukla hafiften kritik derecede ağır klinik tablolara kadar değişen semptomlar gösterir. Ateş, kas/eklem ağrıları, öksürük, boğaz ağrısı ve nazal konjesyon gibi bulguları olup, takipnesi ( $\geq 30 /$ dakika) mevcut olan, oda havasında SpO2 düzeyi \% 90 alıında olan ve başvuruda alınmış kan tetkiklerinde kötü prognostik ölçütü (kan lenfosit sayısı $<800 / \mu l$ veya $\mathrm{CRP}>40 \mathrm{mg} / \mathrm{l}$ veya ferritin $>500 \mathrm{ng} / \mathrm{ml}$ veya
D-Dimer $>1000 \mathrm{ng} / \mathrm{ml}, \mathrm{vb}$ ) bulunan hastalar ile akciğer grafisinde veya tomografisinde bilateral yaygın pnömoni bulgusu saptanan hastalar ağır pnömoni tablosunda olarak tanımlanır. Öte yandan dispne/ağır solunum sıkıntısı olması, solunum sayısının >30/dk olarak ölçülmesi , PaO2/FiO2 değerinin $<300$ olması, oksijen intiyacının izlemde artış göstermesi, 5 L/dk oksijen tedavisine rağmen $\mathrm{SPO} 2<90$ ve $\mathrm{PaO} 2<70$ olması, hipotansiyonun (sistolik kan basıncı $<90$ mmhg ve olağan sistolik kan basıncından $40 \mathrm{mmHg}$ dan fazla düşüş ve ortalama arter basıncının $<65 \mathrm{mmHg}$ olması) ve taşikardinin mevcudiyeti (nabız >100/dk), akut böbrek hasarı, akut karaciğer fonksiyon testlerinde bozukluk, konfüzyon, akut kanama diyatezi gibi akut organ disfonksiyonu gelişimine işaret eden klinik bulguların varlığı, hastanın immunsuprese olması, troponin değerlerinin yüksek olması, aritmilerin izlenmesi, serum laktat değerinin $>2 \mathrm{mmol}$ olması ve/veya kapiller geri dönüş bozukluğu, kutis marmaratus gibi cilt patolojilerinin mevcudiyeti durumunda hastanın yoğun bakıma yatıııması düşünülmelidir (3). Vakaların \%80'inde hafif pnömoni semptomları, \%15'inde dispne, hipoksi ve yaygın akciğer tutulumu bulguları gösteren ciddi klinik tablo ve \%5'inde ağır solunum sıkıntısı, şok ve çoklu organ yetmezliği ile seyreden çok ağır kritik klinik sonuçlar gözlenmektedir. Hastalığa yakalanan popülasyonda yaklaşık mortalite oranı \%2-3'lerdedir (3). Her yaş grubunda görülebilmekle beraber ağır hastalık çoğunlukla mevcut komorbit hastalığı olan ileri yaş grubu şahıslarda izlenmektedir (9). Hastalık çoğunlukla yüksek ateş, öksürük, nefes darlığı ve radyolojik görüntülemelerde saptanan bilateral pulmoner infiltrasyonlar ile kendisini gösterir. COVID-19 enfeksiyonunu diğer viral pnömoni tablolarından spesifik olarak ayırt edebilecek klinik bir bulgu mevcut değildir (10). Tam kan sayımında lökopeni, lökositoz ve lenfopeni (en sık) izlenebilir. Yükselmiş ferritin, LDH ve aminotransferaz düzeyleri de bildirilmiştir. Bunun yanında yükselmiş $\mathrm{CRP}$, prokalsitonin ve D-dimer seviyeleri de izlenebilir. Yükselmiş D-dimer seviyeleri ve ciddi lenfopeni mortalite ile ilișkili bulunmuştur (11). COVID-19'lu hastalarda göğüs BT'si, çoğunlukla viral pnömoni ile uyumlu konsolidasyon bulguları veya "buzlu cam" opasitelerini gösterir. Görüntüleme bulguları çoğunlukla bilateral, periferik dağılımlıdır ve alt lobları içerir. Daha nadir olarak plevral kalınlaşma, plevral efüzyon ve lenfadenopatiler de gözlenebilir (12). COVID-19 olasılığı öncelikle yeni ateş ve / veya solunum yolu semptomları 
olan hastalarda (örn. Öksürük, nefes darlığı) düşünülmelidir. Açık bir nedeni olmayan şiddetli alt solunum yolu hastalığı olan hastalarda da dikkate alınmalıdır. Özellikle: 1) Son 14 gün içinde enfeksiyonun yoğun olarak gözlendiği bir bölgeye seyahat öyküsü olanlar ve 2) Enfeksiyon şüphesi olan bireylerle son 14 gün içerisinde yakın temas öyküsü olanlar, bu enfeksiyon açısından yüksek risk altındadır. Şüpheli vakalarda tanı, alt (daha duyarlı) ve/veya üst solunum yollarından alınan örneklerin kantitatif revers transkripsiyon polimeraz zincir reaksiyonu (qRT-PCR) analizi ile konulmaktadır. Illk test negatif olan yüksek şüpheli vakalarda test tekrarlanır. Eğer iki qRT-PCR analizi de negatif ise genellikle COVID-19 dışlanır (3). Enzyme-linked immunosorbent assay (ELISA) yöntemi ile serolojik testler de gerçekleştirilebilmekle beraber, klinik uygulamalarda henüz yaygın kullanım alanı bulamamıştır (13).

Hafif vakaların ayaktan ve 14 günlük kişisel izolasyon koşullarına riayet ederek takibi uygun olabilmekle beraber, daha ağır vakalarda solunum desteği, parenteral tedaviler ve hastalığa bağlı komplikasyonların etkin bir biçimde tedavisi için hospitalizasyon gerekmektedir. Maalesef hastalığın henüz bir aşısı ya da spesifik tedavisi bulunamamıştır. Tedavide Remdesivir, hidroksiklorakin, lopinavir-ritonavir, tocilizumab, favipiravir gibi ilaçlar üzerinde çalışmalar mevcuttur (8).

Mevcut viral patojen ile ilgili bilgi birikimimiz henüz kısıtı olduğundan, COVID-19 enfeksiyonunun gebelik üzerine olan etkileri net olarak ortaya konulamamıştır. Buna karşın elimizdeki sınırı bilgilerin ışığında gebeliğin bulaş riskini arttırmadığı, hastalığın prognozunu kötüleştirmediği ve gebelerin büyük kısmının hastalığı kendi yaş gruplarındaki bireylerle benzer biçimde geçirebileceği düşünülmektedir (9, 14-17). Öte yandan gebelikte kardiyovasküler, respiratuar, hematolojik ve immünolojik sistemler başta olmak üzere pek çok organ sisteminde adaptif değişiklikler meydana gelmektedir. Bahsi geçen fizyolojik olayların gebe popülasyonunu enfeksiyon hastalıklarına karşı daha korumasız hale getirebileceği ve ağır hastalık tablosuna ilerlemenin daha sık görülebileceği yönünde endişeler de mevcuttur $(18,19)$. Bunun yanında gebe hastaların takibi, olası obstetrik komplikasyonların yönetimi, doğum zamanlaması ve yöntemi, enfeksiyonun gebe popülasyonda yönetimi, medikasyonların güvenilirliği, sağlık personelinin korunması, kötü prognostik faktörlerin belirlenmesi, anneden bebeğe vertikal geçiş riski, postpartum hasta bakımı ve emzirme uygulamaları gibi mevcut hasta grubuna özel pek çok konuda henüz fikir birliği bulunmamaktadır. Bu amaçla dünya çapında pek çok dernek ve kuruluş kendi kılavuzlarını yayınlamıştır (20-26). Bu derlemeyi yazmamızdaki amaç COVID-19 enfeksiyonu olan gebelerin sonuçlarını uluslararası literatür bazında gözden geçirmek ve bahsi geçen gebelerin obstetrik olarak yönetiminde klinisyenlere katkıda bulunmaktır.

\section{Gebelikte COVID-19 Enfeksiyonunun Klinik Seyri}

Virüsün gebelerde genel popülasyon ile benzer semptomlara yol açı̆̆ı düşünülmektedir. Çoğunlukla soğuk algınlığı ve grip benzeri bir klinik tablo mevcuttur. Daha önceki koronavirüs etkenleri olan Severe Acute Respiratory Syndrome Coronavirus (SARSr-CoV) ve Middle East Respiratory Syndrome Coronavirus (MERSr-CoV) 'a nazaran daha IIımlı bir klinik izlenmektedir (15, 27). Mevcut literatürde özellikle iki çalışmanın sonuçları dikkat çekmektedir. İlki Zaigham ve ark. tarafından yapılmış olan sistematik derlemenin sonuçlarıdır (27). Bahsi geçen çalışmada 12.02.2020-04.04.2020 tarihleri arasında MEDLINE, EMBASE ve Google Scholar veri tabanlarında yayınlanmış olan vaka serileri retrospektif olarak taranmış ve toplam 108 hastanın sonuçlarını içeren 18 makalenin analizi yapıımıştır. Bu çalışmanın sonuçları doğrultusunda hastane başvurularının büyük kısmının son trimesterde yapıldığı (\%80), ateş (\%68) ve öksürüğün (\%34) en sık başvuru semptomları olduğu, lenfositopeni $(\% 59)$ ile CRP yüksekliğinin (\%70) en sık laboratuvar bulguları olduğu ve son olarak vakaların \%91'inde sezaryen ile doğum yaptırılığı ortaya konulmuştur. Üç vaka yoğun bakım servisinde takip edilmiş olup maternal ölüm bildirilmemiştir. Yine mevcut serilerde bir neonatal ölüm ve bir intrauterin ölüm gerçekleşmiştir. Yazarlar hastalığın gebelikte çoğunlukla ılımlı seyrettiğini fakat bazı vakalarda ağır klinik seyir izlenebileciğini, anneden bebeğe vertikal geçişin dışlanamadığını ve her ne kadar maternal mortalite olmasa da neonatal ve intrauterin ölümlerin izlendiğini vurgulamıştır (27). İkinci çalışma Breslin ve ark. tarafından 09.04.2020 tarihinde yayınlanmış olan 43 hastalık seridir (15). Bu seride 14 (\%32.6) hastada herhangi bir klinik bulgunun mevcut olmadığı vurgulanmıştır. Bu 14 hastanın 10'u (\%71.4) doğum için başvuruda ya da postpartum dönemde klinik bulgu göstermiştir. Geriye kalan 29 (\%67.4) hastanın 3'ü (\%10.3) antenatal dönemde ve 1'i (\%3.4) postpartum dönemde solunum sıkıntısı sebebiyle hospitalize edilmiştir. Gerçekleştirilen ilk testler sonucunda neontal enfeksiyona rastlanılmamıştır. 37 (\%86) hastada hafif, $4(\% 9.3)$ hastada ağır ve $2(\% 4.7)$ hastada kritik derecede ağır klinik tablo gelişmiştir. Mevcut hastalardan 18'i (\%41.8) doğum yapmıştır. Doğumların 8'i (\%44.4) sezaryen ile 10'u (\%55.6) normal spontan vajinal yol ile gerçekleş- tirilmiştir. Sezaryen doğumlar obstetrik endikasyonlar doğrultusunda gerçekleştirilmiştir. Doğum yapan tüm hastalar rejyonel anestezi almıştı, sadece bir vakada intraoperatif kanama nedeniyle genel anesteziye dönülmüştür (15). Yani elimizdeki sınırı literatür bilgisi doğrultusunda COVID-19 enfeksiyonunun gebelikte nisbeten ılımlı seyrettiği ve gebeliğin gidişatını genellikle olumsuz yönde etkilemediği düşünülebilir. Öte yandan bazı vakalarda yoğun bakım intiyacının gelişmesi, intrauterin/neonatal ölüm vakalarının olması, artmış sezaryen oranları gibi faktörler göz önünde bulundurularak gebe hasta popülasyonunda dikkatli olunmalıdır. Ayrıca son dönemde bir maternal mortalite vakası da bildirilmiştir (28).

Tablo 1'de 15.04.2020 tarihi itibari ile literatürde sunulmuş olan vaka serilerinin özeti yapılmıştır $(7,10,14,15,28-43)$.

Tablo 1: Literatürdeki vaka serilerinin özeti

\begin{tabular}{|c|c|c|c|c|c|c|}
\hline Yazar & Ülke & \begin{tabular}{|l|} 
Vaka \\
sa- \\
yIsI \\
\end{tabular} & \begin{tabular}{|l|} 
Vakaların \\
demografik \\
özellikleri \\
\end{tabular} & $\begin{array}{l}\text { Vakaların kli- } \\
\text { nik özellikleri }\end{array}$ & $\begin{array}{l}\text { Laboratuvar } \\
\text { bulguları }\end{array}$ & $\begin{array}{l}\text { Maternal ve Obs- } \\
\text { tetrik sonuçlar }\end{array}$ \\
\hline Chen $\mathrm{H}$. & Çin & 9 & \begin{tabular}{|l|}
$26-40$ yaş \\
arası, $36-$ \\
$39^{4}$ gebelik \\
haftası
\end{tabular} & $\begin{array}{l}\text { Kronik has- } \\
\text { talık yok, } \\
\text { gestasyonel } \\
\text { hipertan- } \\
\text { siyon (1), } \\
\text { preeklampsi } \\
(1), \text { vakaların } \\
\text { hepsinde } \\
\text { temas öy- } \\
\text { küsü, ateş } \\
(7 / 9)(\% 77.7), \\
\text { öksürük (4/9) } \\
(\% 44.4), \\
\text { miyalji (3/9) } \\
(\% 33.3), \\
\text { boğaz ağrısı } \\
(2 / 9)(\% 22.2), \\
\text { kırgınlık } \\
(\% 22.2), \text { gas- } \\
\text { tointestinal } \\
\text { semptom } \\
(1 / 9)(\% 11.1)\end{array}$ & \begin{tabular}{|l} 
Lenfopeni (5/9) \\
(\%55.5), CRP \\
yüksekliği (6/9) \\
$(\% 66.6)$, KCFT \\
yüksekliği (3/9) \\
(\%33.3), Akciğer \\
BT'de tipik bulgu \\
$(8 / 9)(\% 88.8)$
\end{tabular} & \begin{tabular}{|l} 
Ağır klinik ya da \\
maternal ölüm \\
yok, Preterm \\
doğum (4/9) \\
(\%44.4), intrau- \\
terin/neonatal \\
ölüm yok, 1-5. Dk \\
Apgar $\geq 8,<2500$ \\
g (2/9)(\%22.2), \\
doğum kilosu \\
$1880-3730$ g ara- \\
sında,Tüm vakalar \\
sezaryen, 6 has- \\
tadan toplanan \\
amniyotik sIVI, \\
kord kanı, neona- \\
tal boğaz sürün- \\
tüsü ve anne sütü \\
örnekleri RT-PCR \\
negatif, vertikal \\
geçiş yok
\end{tabular} \\
\hline Liu Y. & Çin & 13 & \begin{tabular}{|l|}
$22-36$ yaş \\
arası, $25-$ \\
$38^{3}$ gebelik \\
haftası
\end{tabular} & $\begin{array}{l}\text { Ateş (10/13) } \\
(\% 77), \text { Dispne } \\
(3 / 13)(\% 23), \\
\text { semptomsuz } \\
(1 / 13)(\% 7.6), \\
\text { temas öykü- } \\
\text { sü }(12 / 13) \\
(\% 92.3)\end{array}$ & & $\begin{array}{l}3 \text { hastada sorun- } \\
\text { suz devam eden } \\
\text { gebelik }(\% 23.1), \\
10 \text { doğumun hep- } \\
\text { si sezaryen, fetal } \\
\text { distres }(3 / 10) \\
(\% 30), \text { erken } \\
\text { membran rüptürü } \\
(1 / 10)(\% 10), \\
\text { intrauterin ölüm } \\
(1 / 10)(\% 10), \\
\text { preterm doğum } \\
(6 / 13)(\% 46), \\
1 \text { vakada kötü } \\
\text { prognoz ARDS ve } \\
\text { ECMO intiyacl, } 1 . \\
\text { Dk Apgar } 10, \text { ver- } \\
\text { tikal geçiş yok }\end{array}$ \\
\hline Li Y. & Çin & 1 & $\begin{array}{l}30 \text { yaş, } 35 . \\
\text { gebelik } \\
\text { haftası }\end{array}$ & $\begin{array}{l}\text { Temas öy- } \\
\text { küsü pozitif, } \\
\text { ateş, öksürük, } \\
\text { dispne }\end{array}$ & $\begin{array}{l}\text { Akciğer grafisin- } \\
\text { de bilateral tutu- } \\
\text { lum, lenfopeni, } \\
\text { CRP yüksekliği }\end{array}$ & $\begin{array}{l}35^{3} \text { haftada fetal } \\
\text { distres nedeniyle } \\
\text { sezaryen, neona- } \\
\text { tal komplikasyon } \\
\text { yok, vertikal geçiş } \\
\text { yok, maternal } \\
\text { komplikasyon yok }\end{array}$ \\
\hline Fan C. & Çin & 2 & \begin{tabular}{|l|}
34 yaş, 37. \\
gebelik \\
haftası ve \\
29 yaş, 36. \\
gebelik \\
haftası
\end{tabular} & $\begin{array}{l}\text { iki vakada } \\
\text { da temas } \\
\text { öyküsü, } \\
\text { ateş, burun } \\
\text { akıntısı, } \\
\text { boğaz ağrısı, } \\
1 \text { vakada } \\
\text { döküntülü } \\
\text { lezyon }\end{array}$ & $\begin{array}{l}\text { Her } 2 \text { vakada } \\
\text { ToraksBBT'de } \\
\text { bulgu, } 1 \text { vakada } \\
\text { lenfopeni, }\end{array}$ & $\begin{array}{l}\text { 39. gebelik haf- } \\
\text { tasında, } 3400 \text { g, } \\
9 / 10 \text { Apgar,sezar- } \\
\text { yen ve } 36^{5} \text { gebelik } \\
\text { haftasında, } 2890, \\
9 / 10 \text { Apgar, sezar- } \\
\text { yen doğumlar, her } \\
2 \text { vakada klinik } \\
\text { olarak neonatal } \\
\text { enfeksiyon şüp- } \\
\text { hesi fakat negatif } \\
\text { PCR, maternal } \\
\text { komplikasyon yok }\end{array}$ \\
\hline Zhu H. & Çin & 9 & $\begin{array}{l}25-35 \text { yaş } \\
\text { arası, } 31- \\
39 \text { gebelik } \\
\text { haftaları, } \\
10 \text { yeni- } \\
\text { doğan (bir } \\
\text { ikiz) }\end{array}$ & \begin{tabular}{|l} 
Ateş (7/9) \\
(\%77.7), \\
öksürük (4/9) \\
$(\% 44.4)$, \\
boğaz ağrısı \\
$(1 / 9)(\% 11.1)$, \\
diyare (1/9) \\
(\%11.1), \\
semptomlar \\
doğumdan \\
önce (4/9) \\
(\%44.4), \\
doğumda \\
$(2 / 9)(\% 22.2)$, \\
doğumdan \\
sonra (3/9) \\
(\%33.3)
\end{tabular} & $\begin{array}{l}2 \text { yenidoğanda } \\
\text { trombositopeni } \\
\text { ve bozulmuş ka- } \\
\text { raciğer enzimleri }\end{array}$ & $\begin{array}{l}\text { 31-39 haftalar } \\
\text { arası, 1520-3800 } \\
\text { g, sezaryen }(7 / 9) \\
(\% 77.7) \text {, fetal } \\
\text { distres }(6 / 10) \\
(\% 60) \text {, erken me- } \\
\text { mebran rüptürü } \\
(3 / 10)(\% 30), \text { SGA } \\
(2 / 10)(\% 20), \text { LGA } \\
(1 / 10)(\% 10), \text { Ap- } \\
\text { gar >7, neonatal } \\
\text { DIC }(2 / 10)(\% 20 \\
\text { ), neonatal ölüm } \\
(1 / 10)(\% 10), \\
\text { vertikal geçiş gös- } \\
\text { terilememiş }\end{array}$ \\
\hline
\end{tabular}




\begin{tabular}{|c|c|c|c|c|c|c|}
\hline Wang S. & Çin & 1 & \begin{tabular}{|l|}
34 yaş, 40. \\
gebelik \\
haftası
\end{tabular} & $\begin{array}{l}\text { Temas öykü- } \\
\text { sü mevcut, } \\
\text { ateş }\end{array}$ & \begin{tabular}{|l|} 
Toraks BT'de bul- \\
gular, lenfopeni, \\
CRP yüksekliği
\end{tabular} & \begin{tabular}{|l}
3205, Apgar \\
$8 / 9$, sezaryen, \\
mekonyumlu, \\
postpartum 36. \\
Saat neonatal \\
faringeal sürüntü \\
PCR pozitif, ma- \\
ternal komplikas- \\
yon yok
\end{tabular} \\
\hline Chen S. & Çin & 3 & \begin{tabular}{|l|} 
Üçüncü \\
trimester \\
gebelikleri
\end{tabular} & $\begin{array}{l}\text { Vakaların } \\
\text { tümünde } \\
\text { ateş, temas } \\
\text { öyküsü }\end{array}$ & $\begin{array}{l}\text { Normal plasental } \\
\text { morfoloji ve PCR }\end{array}$ & $\begin{array}{l}\text { Tüm vakalarda } \\
\text { acil sezaryen, pre- } \\
\text { term doğum (1/9) } \\
\text { (\%33.3), maternal } \\
\text { komplikasyon } \\
\text { yok, } 3 \text { plasenta- } \\
\text { nın morfolojisi ve } \\
\text { PCR'ı negatif }\end{array}$ \\
\hline $\begin{array}{l}\text { Zambra- } \\
\text { no LI. }\end{array}$ & \begin{tabular}{|l|} 
Hondu- \\
ras
\end{tabular} & 1 & \begin{tabular}{|l|}
41 yaş, 31. \\
gebelik \\
haftası,
\end{tabular} & $\begin{array}{l}\text { Gestasyonel } \\
\text { hipertansiyon } \\
\text { ve hipotiro- } \\
\text { idizm, ateş } \\
\text {,öksürük, baş } \\
\text { ağrısı, myalji, } \\
\text { temas öykü- } \\
\text { sü, bilateral } \\
\text { konjuktival } \\
\text { hiperemi, }\end{array}$ & $\begin{array}{l}\text { Fetal tek taraflı } \\
\text { multikistik } \\
\text { displastik böbrek }\end{array}$ & $\begin{array}{l}\text { Gebelik devam } \\
\text { ediyor }\end{array}$ \\
\hline Wang X. & Çin & 1 & $\begin{array}{l}28 \text { yaş, } \\
30 \text { hafta } \\
\text { gebelik }\end{array}$ & $\begin{array}{l}\text { Temas öykü- } \\
\text { sü, ateş }\end{array}$ & $\begin{array}{l}\text { Göğüs BT'de } \\
\text { tutulum, nazofa- } \\
\text { rangeal sürüntü } \\
\text { PCR negatif, bal- } \\
\text { gam PCR pozitif, } \\
\text { lenfopeni }\end{array}$ & \begin{tabular}{|l}
$30^{6}$ gestasyonel \\
hafta, fetal \\
distres, sezaryen \\
ile $1830 \mathrm{~g}, 9 / 10$ \\
Apgar doğum, \\
vertikal geçiş ve \\
maternal kompli- \\
kasyon yok
\end{tabular} \\
\hline Gidlöf S. & İsveç & 1 & $\begin{array}{l}34 \text { yaş, } \\
36^{2} \text { hafta } \\
\text { gebelik }\end{array}$ & \begin{tabular}{|l|} 
Dikoryonik \\
diamniyotik \\
ikiz gebelik, \\
gestasyonel \\
diyabet, ma- \\
ternal obezi- \\
te, preeklam- \\
psi, baş ağrısı, \\
ses kısıklığı \\
ve halsizlik, \\
ateş \\
\end{tabular} & $\begin{array}{l}\text { Nazofarengeal } \\
\text { PCR pozitif }\end{array}$ & \begin{tabular}{|l|} 
Preeklampsi \\
nedeniyle, \\
$2680 / 2160 \mathrm{~g}$, \\
sezaryen, $9 / 10$ \\
Apgar, vertikal \\
geçiş ve maternal \\
komplikasyon yok
\end{tabular} \\
\hline Yu N. & Çin & 7 & \begin{tabular}{|l|}
$29-34$ \\
yaş arası, \\
$37-41^{2}$ ges- \\
tasyonel \\
hafta
\end{tabular} & \begin{tabular}{|l|} 
Ateş(6/7) \\
(\%86), ök- \\
sürük (1/7) \\
$(\% 14)$, dispne \\
$(1 / 7)(\% 14)$, \\
diyare $(1 / 7)$ \\
$(\% 14)$, tüm \\
vakalarda \\
temas öyküsü \\
pozitif \\
\end{tabular} & $\begin{array}{l}\text { Lenfopeni (5/7) } \\
\text { (\%71), platelet } \\
\text { düşüklüğü }(2 / 7) \\
(\% 29), \text { tüm } \\
\text { hastalarda } \\
\text { yüksek D-Dimer, } \\
\text { karaciğer enzim } \\
\text { yğksekliği }(2 / 7) \\
\text { (\%29) }\end{array}$ & \begin{tabular}{|l|} 
Tüm vakalarda \\
sezaryen, $3000-$ \\
$3500 \mathrm{~g}, 8-10$ \\
Apgar, vertikal \\
geçiş ve maternal \\
komplikasyon yok
\end{tabular} \\
\hline $\begin{array}{l}\text { Breslin } \\
\mathrm{N} .\end{array}$ & \begin{tabular}{|l|} 
Amerika \\
Birleşik \\
Devlet- \\
leri \\
\end{tabular} & 7 & $\begin{array}{l}27-39 \text { yaş, } \\
26^{3}-37^{5} \\
\text { gebelik } \\
\text { haftaları }\end{array}$ & $\begin{array}{l}\text { Tip 2 diyabet } \\
(2 / 7)(\% 29), \\
\text { kronik hi- } \\
\text { pertansiyon } \\
(1 / 7)(\% 14), \\
\text { astım }(1 / 7) \\
(\% 14), \text { ateş } \\
(2 / 7)(\% 29), \\
\text { öksürük (3/7) } \\
(\% 42.8) \\
\text { miyalji }(2 / 7) \\
(\% 29), \text { göğüs } \\
\text { ağrısı }(2 / 7) \\
(\% 29), \text { baş } \\
\text { ağrısı }(2 / 7) \\
(\% 29), \text { temas } \\
\text { öyküsü }(2 / 7) \\
(\% 29),\end{array}$ & $\begin{array}{l}\text { Belirgin patoloji } \\
\text { yok }\end{array}$ & $\begin{array}{l}2 \text { maternal yoğun } \\
\text { bakım yatişı (2/7) } \\
(\% 29)\end{array}$ \\
\hline Iqbal SN. & \begin{tabular}{|l|} 
Amerika \\
Birleşik \\
Devlet- \\
leri
\end{tabular} & 1 & $\begin{array}{l}34 \text { yaş, } \\
39 \text { hafta } \\
\text { gebelik, }\end{array}$ & \begin{tabular}{|l|} 
Ateş, üşü- \\
me-titreme, \\
kuru mksü- \\
rük, miyalji, \\
temas öyküsü \\
pozitif \\
\end{tabular} & $\begin{array}{l}\text { Direkt göğüs gra- } \\
\text { fisinde bulgular, } \\
\text { lenfopeni }\end{array}$ & \begin{tabular}{|l|} 
Vajinal doğum, \\
9/10 Apgar, \\
vertikal geçiş ve \\
maternal kompli- \\
kasyon yok
\end{tabular} \\
\hline Lee DH. & \begin{tabular}{|l|} 
Güney \\
Kore
\end{tabular} & 1 & \begin{tabular}{|l|}
28 yaş, $36^{2}$ \\
gebelik \\
haftası
\end{tabular} & $\begin{array}{l}\text { Temas öy- } \\
\text { küsü, ateş, } \\
\text { boğaz ağrısı, } \\
\text { öksürük }\end{array}$ & $\begin{array}{l}\text { Direk grafi ve } \\
\text { göğüs BT'de bul- } \\
\text { gular, sedimen- } \\
\text { tasyon yüksekliği }\end{array}$ & \begin{tabular}{|l|}
$37^{6}$, ilerlemeyen \\
eylem sezaryen, \\
spinal anestezi, \\
$3130 \mathrm{~g}, 9 / 10$ \\
Apgar, maternal \\
komplikasyon ve \\
vertikal geçiş yok
\end{tabular} \\
\hline Liu $\mathrm{H}$. & Çin & 16 & \begin{tabular}{|l|}
$22-42$ yaş, \\
$22-40^{5}$ ges- \\
tasyonel \\
hafta (Ça- \\
lışmadaki \\
toplam 41 \\
gebe hasta \\
için) \\
\end{tabular} & $\begin{array}{l}\text { Ateş (7/16) } \\
(\% 43.7), \text { ök- } \\
\text { sürük (6/16) } \\
(\% 37.5), \text { kır- } \\
\text { gınlık (3/16) } \\
(\% 18.7), \\
\text { dispne (3/16) } \\
(\% 18.7) \\
\end{array}$ & $\begin{array}{l}\text { Lenfopeni } \\
(9 / 16)(\% 56.2), \\
\text { CRP yüksekliği } \\
(13 / 16)(\% 81.2), \\
\text { tüm vakalarda } \\
\text { göğüs BT bul- } \\
\text { guları }\end{array}$ & $\begin{array}{l}\text { Doğuran } 6 \text { hasta- } \\
\text { nın hepsinde se- } \\
\text { zaryen, maternal } \\
\text { mortalite yok }\end{array}$ \\
\hline
\end{tabular}

\begin{tabular}{|c|c|c|c|c|c|c|}
\hline Zhang I. & Çin & 16 & \begin{tabular}{|l|} 
Ortalama \\
anne yaşı \\
29, orta- \\
lama ges- \\
tasyonel \\
hafta 36
\end{tabular} & \begin{tabular}{|l|} 
Öksürük \\
$(3 / 16)$ \\
$(\% 37.5)$, \\
dispne $(3 / 16)$ \\
$(\% 37.5)$, \\
diyare $(3 / 16)$ \\
$(\% 37.5)$ \\
\end{tabular} & & $\begin{array}{l}\text { Gerçekleşen } 16 \\
\text { doğumun tümü } \\
\text { sezaryen }\end{array}$ \\
\hline Liu D. & Çin & 15 & $\begin{array}{l}23-40 \text { yaş, } \\
12-38 \\
\text { gebelik } \\
\text { haftası }\end{array}$ & \begin{tabular}{|l|} 
Ateş $(13 / 15)$ \\
$(\% 86.6)$, mk- \\
sürük $(9 / 15)$ \\
$(\% 60)$, kır- \\
gınlık $(4 / 15)$ \\
$(\% 26.6)$, \\
miyalji $(3 / 15)$ \\
$(\% 20)$, dispne \\
$(1 / 15)(\% 6.6)$, \\
boğaz ağrısı \\
$(1 / 15)(\% 6.6)$, \\
diyare $(1 / 15)$ \\
$(\% 6.6)$
\end{tabular} & \begin{tabular}{|l} 
Lenfopeni \\
$(12 / 15)(\% 80)$, \\
CRP yüksek- \\
liği $(10 / 15)$ \\
(\%66.6),tüm \\
vakalarda toraks \\
BT bulguları
\end{tabular} & $\begin{array}{l}\text { Doğum yapan } 11 \\
\text { hastanın } 10^{\prime} \text { u se- } \\
\text { zaryen }(\% 90.9)\end{array}$ \\
\hline Chen S. & Çin & 5 & \begin{tabular}{|l}
$25-31$ yaş, \\
$38-41$ ges- \\
tasyonel \\
hafta
\end{tabular} & $\begin{array}{l}\text { Temas öykü- } \\
\text { sü, öksürük } \\
(1 / 5)(\% 20), \\
\text { balgam }(1 / 5) \\
(\% 20), \text { burun } \\
\text { akıntısı }(1 / 5) \\
(\% 20), \text { gestas- } \\
\text { yonel diyabet } \\
(2 / 5)(\% 40) \text {, } \\
\text { preeklampsi } \\
(1 / 5)(\% 20 \\
\text { ), tüm vaka- } \\
\text { larda doğum } \\
\text { sonrası } 24 \\
\text { saat içerisin- } \\
\text { de ateş } \\
\end{array}$ & $\begin{array}{l}\text { Kardiyak enzim- } \\
\text { lerde yükselme } \\
(2 / 5)(\% 40), \text { to- } \\
\text { raks BT'de bilate- } \\
\text { ral }(3 / 5)(\% 60) \text { ve } \\
\text { unilateral }(2 / 5) \\
(\% 40) \text { tutulum, }\end{array}$ & $\begin{array}{l}38^{6}-40^{4} \text { gestas- } \\
\text { yonel haftalar } \\
\text { arası, } 3235-4050 \\
\text { g arası, } 10-10 \\
\text { Apgar, sezaryen } \\
\text { oranı }(2 / 5)(\% 40), \\
\text { vertikal geçiş yok, } \\
\text { maternal kompli- } \\
\text { kasyon yok }\end{array}$ \\
\hline $\begin{array}{l}\text { Breslin } \\
\mathrm{N} .\end{array}$ & \begin{tabular}{|l} 
Amerika \\
Birleşik \\
Devlet- \\
leri
\end{tabular} & 43 & \begin{tabular}{|l}
$20-39$ yaş \\
arası, $32^{4}-$ \\
$38^{6}$ ges- \\
tasyonel \\
haftalar
\end{tabular} & $\begin{array}{l}\text { Obezite } \\
(26 / 43) \\
(\% 60.5), \text { ek } \\
\text { komorbidite } \\
(18 / 43) \\
(\% 41.8), \text { ök- } \\
\text { sürük (19/43) } \\
(\% 44.1), \\
\text { ateş (14/43) } \\
\text { (\%32.5), mi- } \\
\text { yalji (11/43) } \\
(\% 25.6), \\
\text { Dispne (7/43) } \\
\text { (\%16.2), } \\
\text { göğüs ağ- } \\
\text { rısı (5/43) } \\
\text { (\%11.6), baş } \\
\text { ağrısı (8/43) } \\
\text { (\%18.6), } \\
\text { temas öykü- } \\
\text { sü (10/43) } \\
\text { (\%23.2), } \\
\text { vakaların } \\
\% 32.5^{\prime} \text { i } \\
\text { başvuruda } \\
\text { asemptoma- } \\
\text { tik (14/43), } \\
\text { ağır semp- } \\
\text { tomlar (3/43) } \\
\text { (\%6.9) }\end{array}$ & & $\begin{array}{l}18 \text { doğumun } 8^{\prime} i \\
\text { sezaryen (\%44.4), } \\
\text { hepsi rejyonel (1 } \\
\text { vakada kanama } \\
\text { nedeniyle genele } \\
\text { dönülmüş), ver- } \\
\text { tikal geçiş yok, } \\
\text { maternal yoğun } \\
\text { bakım (2/43) } \\
\text { (\%4.6), maternal } \\
\text { mortalite yok }\end{array}$ \\
\hline $\begin{array}{l}\text { Ferraz- } \\
\text { zi E. }\end{array}$ & italya & 42 & & \begin{tabular}{|l|} 
Interstisyel \\
pnömoni \\
$(20 / 42)(\% 48)$
\end{tabular} & & $\begin{array}{l}\text { Sezaryen doğum } \\
(18 / 42)(\% 43), \\
\text { spontan preterm } \\
\text { doğum (2/42) } \\
\text { (\%4.7), maternal } \\
\text { yoğun bakım yat-- } \\
\text { şı (7/42)(\%16.6) }\end{array}$ \\
\hline Wu X. & Çin & 23 & $\begin{array}{l}21-37 \text { yaş, } \\
6-40 \text { ges- } \\
\text { tasyonel } \\
\text { hafta }\end{array}$ & $\begin{array}{l}\text { Asemptoma- } \\
\text { tik (15/23) } \\
(\% 65.2)\end{array}$ & \begin{tabular}{|l|} 
Toraks BT'de \\
semptomatik \\
vakalarda bilate- \\
ral ve daha ileri \\
bulgular
\end{tabular} & $\begin{array}{l}\text { illk başvuru } \\
\text { ve radyolojik } \\
\text { gerileme } \\
\text { arasındaki } \\
\text { lenfosit yüzdesi, } \\
\text { nötrofil/ } \\
\text { granülosit oranı } \\
\text { istatistiksel } \\
\text { olarak farkl, } \\
\text { semptomatik ve } \\
\text { asemptomatik } \\
\text { vakalar arasında } \\
\text { radyolojik } \\
\text { gerileme ve } \\
\text { hastanede yatış } \\
\text { süresi istatisitksel } \\
\text { olarak farklı }\end{array}$ \\
\hline
\end{tabular}




\begin{tabular}{|c|c|c|c|c|c|c|}
\hline Xiong $\mathrm{X}$. & Çin & 1 & $\begin{array}{l}25 \text { yaş, } 33^{1} \\
\text { gestasyo- } \\
\text { nel hafta }\end{array}$ & $\begin{array}{l}\text { Ateş, öksü- } \\
\text { rük, üşü- } \\
\text { me-titreme }\end{array}$ & $\begin{array}{l}\text { Direkt grafi ve } \\
\text { PCR pozitifliği }\end{array}$ & \begin{tabular}{|l|} 
Tedavi sonrası \\
PCR negatifleş- \\
miş, $38^{4}$ gestas- \\
yonel hafta, 3070 \\
g, vajinal doğum, \\
9-10-10 Apgar, \\
vertikal geçiş, ma- \\
ternal komplikas- \\
yon yok, neonatal \\
antikor yok
\end{tabular} \\
\hline Khan S. & Çin & \begin{tabular}{|l}
17 \\
\end{tabular} & $\begin{array}{l}24-34 \text { yaş, } \\
35-41 \text { ges- } \\
\text { tasyonel } \\
\text { hafta }\end{array}$ & \begin{tabular}{|l} 
Ateş (3/17) \\
(\%17.6), ök- \\
sürük (6/17) \\
$(\% 35.2)$, \\
diyare (3/17) \\
(\%17.6), \\
burun akın- \\
tisı $(2 / 17)$ \\
$(\% 11.7)$, \\
nefes dar- \\
lığ (2/17) \\
$(\% 11.7)$, bal- \\
gam (1/17) \\
$(55.8)$, hasta \\
ile temas öy- \\
küsü $(15 / 17)$ \\
$(\% 88)$
\end{tabular} & & $\begin{array}{l}17 \text { doğumun } \\
\text { tümü sezaryen, } \\
2300-3750 \mathrm{~g}, \\
\text { fetal-neonatal } \\
\text { ölüm yok, Apgar } \\
\text { skorları 9-10 arası } \\
\text { (sadece } 1 \text { vakada } \\
7-9), \text { preterm } \\
\text { doğum }(5 / 17) \\
\text { (\%29), spontan } \\
\text { preterm doğum } \\
(3 / 17)(\% 18), \text { ne- } \\
\text { onatal pnömoni } \\
\text { (5/17)(\%29), } 2 \\
\text { vakada neonatal } \\
\text { PCR pozitif (2/17) } \\
\text { (\%11.7), vettikal } \\
\text { geçişi gösterecek } \\
\text { bulgu yok, mater- } \\
\text { nal komplikasyon } \\
\text { yok }\end{array}$ \\
\hline Khan S. & Çin & 3 & $\begin{array}{l}27,28,33 \\
\text { yaş, } 38^{2}, \\
34^{6}, 39^{1} \\
\text { gestasyo- } \\
\text { nel hafta }\end{array}$ & $\begin{array}{l}\text { Ateş }(2 / 3) \\
(\% 66.6), \text { ök- } \\
\text { sürük \%100, } \\
\text { göğüs ağrısı } \\
(1 / 3)(\% 33.3),\end{array}$ & $\begin{array}{l}\text { Toraks BT'de bul- } \\
\text { gular pozitif }\end{array}$ & $\begin{array}{l}3 \text { vajinal doğum, } \\
2890,3500,3730 \\
\text { g, Apgar } 8-10 \\
\text { arası, preterm } \\
\text { (1/3)(\%33.3), ne- } \\
\text { onatal/intrauterin } \\
\text { ölüm yok, vertikal } \\
\text { geçiş yok, mater- } \\
\text { nal komplikasyon } \\
\text { yok }\end{array}$ \\
\hline Karami P. & İran & 1 & $\begin{array}{l}27 \text { yaş, } 30^{3} \\
\text { gestasyo- } \\
\text { nel hafta, }\end{array}$ & $\begin{array}{l}\text { Ateş, miyaliji, } \\
\text { öksürük }\end{array}$ & \begin{tabular}{|l|} 
Lökopeni, \\
lenfopeni, CRP \\
yüksekliği, direkt \\
grafi ve toraks \\
BT'de silik bul- \\
gular, \\
\end{tabular} & \begin{tabular}{|l|} 
Spontan vajinal \\
doğum, ex yeni- \\
doğan, maternal \\
ölüm, otopside \\
akciğer materyali \\
PCR pozitif \\
\end{tabular} \\
\hline
\end{tabular}

KCFT: Karaciğer fonksiyon testi, BT: Bilgisayarlı tomografi, ARDS: Akut respiratuar distres sendromu, CRP: C-reaktif protein, PCR: Polimeraz zincir reaksiyonu.

Bilindiği üzere gebelik pek çok immünolojik adaptif değişikliği beraberinde getirmektedir. Implantasyon ve plasentanın gelişimi proinflamatuar, fetusun ile eklerinin reddinin önlenmesi antiinflamatuar ve yine doğum eyleminin başlatılması proinflamatuar süreçleri gerektirmektedir (18). Liu ve ark. Tarafından yayınlanmış olan bir makalede gebelerin COVID-19 enfeksiyonu açısından riskli bir grup olduğu ve enfeksiyonun gebelerde ağır seyir gösterebileceği vurgulanmıştır. Özellikle COVID-19 enfeksiyonunun en önemli tahribat mekanizmalarından birinin abartımış immün yanıt olduğu (sitokin fırtınası), birinci ve son trimesterde bulunan gebelerin mevcut proinflamatuar ortam nedeniyle bu komplikasyona yatkın olabileceği vurgulanmıştır. Yine T ve B yardımcı lenfosit yanıtındaki değişiklikler, Natural Killer Hücrelerinin çeşitli sitokinler ile immün modülasyonu ve gebeliğin organ sistemleri üzerinde meydana getirdiği fizyolojik değişiklikler COVID-19'un gebelerde ağır seyirli enfeksiyon yapabileceği yönünde endişe doğurmuştur (18). Her ne kadar bahsedilen yazı klinik bir araştırma olmayıp daha çok teorik temellere otursa da, klinisyenler gebe hastaların takip ve yönetiminde oldukça dikkatli olmalıdır.

\section{Gebelik Komplikasyonları}

Enfeksiyonun en sık rastlanan semptomunun ateş olması, özellikle ilk trimesterde olan gebelerde nöral tüp defekti ve düşük gibi komplikasyonların artabileceği yönünde bir endişeye sebep olmuştur. Öte yandan literatürde emsal gösterilebilecek bir vaka mevcut değildir ve bu endişe daha çok klasik teorik bilgilere dayanmaktadır (44). Fakat yine de ilk trimesterda yüksek ateşi olan gebelerde parasetamol gibi gebelikte güvenli kabul edilen antipiretikler ile ateşi düşürmenin faydası olabilir.

Özellikle pnömoni gelişen gebelerde preterm eylem, erken membran rüptürü, preeklampsi ve güven vermeyen fetal kalp atım traselerine bağlı olarak artmış sezaryen oranları gibi komplikasyonlarda artış izlenmiştir (17, 45, 46). Di Mascio ve ark. tarafından gerçekleştirilmiş olan ve 41 hastayı içeren bir sistematik derlemede $\% 41.1$ preterm eylem, $\% 18.8$ erken membran rüptürü, $\% 13.6$ preeklampsi, \%91.1 sezaryen doğum, \%2.4 intrauterin ölüm, \%10 neonatal yoğun bakım yatışı ve \%2.4 neonatal ölüm bildirilmiştir (46). Öte yandan vaka sayısının az olması, dahil edilen vakaların ağır enfeksiyon geçiriyor olması ve doğum kararlarının bir kısmının muhtemelen maternal hastalık durumuna göre verilmiş olması bu çalışmanın sonuçları yorumlanırken göz önünde bulundurulması gereken önemli faktörlerdir.

\section{Anneden Bebeğe Vertikal Geçiş Riski}

SARS-CoV-2 kordon kanında saptanamamıştır ve maternal viremi oranları oldukça düşük görünmektedir (7). Yine 38 hastanın bulgularını içeren bir derlemede intrauterin geçişe rastlanmamıştır (45). Öte yandan literatürde muhtemel vertikal bulaşı yansıtan 4 vaka mevcuttur $(47,48)$. Yenidoğanda IgM antikor yüksekliğini yansıtan bir çalışma bulunmakla beraber, seroloji pozitifliğinin intrauterin maruziyete mi yoksa erken neonatal dönemde patojenle temasa bağlı olarak mı geliştiği konusunda kesin kanıt bulunamamıştır $(49,50)$.

\section{Tanı Konulması}

COVID-19 olasılığı öncelikle yeni ateş ve / veya solunum yolu semptomları olan hastalarda (örn. Öksürük, nefes darlığı) düşünülmelidir. Açık bir nedeni olmayan şiddetli alt solunum yolu hastalığı olan hastalarda da dikkate alınmalıdır. Özellikle: 1) Son 14 gün içinde enfeksiyonun yoğun olarak gözlendiği bir bölgeye seyahat öyküsü olanlar ve 2) Enfeksiyon şüphesi olan bireylerle son 14 gün içerisinde yakın temas öyküsü olanlar, bu enfeksiyon açısından yüksek risk altındadır. Şüpheli vakalarda tanı, alt (daha duyarlı) ve/veya üst solunum yollarından alınan örneklerin kantitatif revers transkripsiyon polimeraz zincir reaksiyonu (qRT-PCR) analizi ile konulmaktadır. İlk test negatif olan yüksek şüpheli vakalarda test tekrarlanır. Eğer iki qRT-PCR analizi de negatif ise COVID-19 dışlanır. Klinik şüphenin yüksek olduğu vakalarda alt solunum yolu örneklerinin incelenmesi önerilmektedir. Ayrıca COVID-19 enfeksiyonu açısından test yapılması gereken hastalar influenza ve respiratuar sinsityal virüs gibi diğer solunum yolu patojenleri açısından da taranmalıdır (3). Gebelerde akciğer grafisi ve göğüs bilgisayarlı tomografisi klinik gereklilik halinde uygulanabilir. Tek çekimlik direkt grafide fetusun maruz kaldığı radyasyon dozu oldukça düşüktür (0.0005- $0.01 \mathrm{mGy}$ ) ve standart göğüs tomografisindeki radyasyon dozu da nisbeten düşük olup (0.01-0.66 mGy) herhangi bir fetal anomali ya da gebelik kaybı ile ilişkilendirilememiştir (51). Gebe hastalarda akciğer görüntülemesinde bir başka alternatif de göğüs ultrasonografisi olabilir (52). Göğüs ultrasonografisinde $3.5 \mathrm{MHz}$ konveks ultrason probu vasıtası ile akciğerin üç yüzeyinin üst ve alt kısımları bilateral olarak transvers/longitidunal planlarda taranır. Fizyolojik A-çizgilerinin patolojik olarak kabul gören B-çizgileri ile değişmesi akciğer tutulumu yönünde bilgi verir (52).

\section{Prenatal Bakım}

The American College of Obstetricians and Gynecologists (ACOG) ve the Society for Maternal-Fetal Medicine (SMFM) rutin prenatal takip protokollerinde bazı modifikasyonlar gerçekleştirilmesini önermiştir $(20,21)$. Bu doğrultuda gebeler yüksek (diyabet, hipertansiyon, çoğul gebelik vs.) ve düşük riskli olarak gruplanmalı, bu doğrultuda antenatal vizitler mümkün olduğunca kısaltılmalıdır. Televizitler, vizite katılan hasta sayısının azaltılması, vizit aralıklarının uzatılması, bir vizitte pek çok taramanın birlikte gerçekleştirilmesi (anöploidi, diyabet ve konjenital enfeksiyon gibi) ve takip boyunca uygulanan ultrasonografi, non-stres test, biyofizik profili gibi tetkiklerin azaltılması yararlı görünmektedir. Kromozomal anomali taraması amacı ile maternal kandaki serbest fetal DNA'nın değerlendirildiği non-invaziv prenatal testler de şu dönem için güvenli bir alternatif olarak düşünülebilir. Hatta düşük risk grubundaki gebelerin 4 kontrol ile sınırlandırıması mantıkı bulunmuştur. Takipler esnasında sağlık personeli ve hasta en azından cerrahi maske kullanmalı, ultrason süresi mümkün oldukça kısa tutulmalı, hasta ile ultrasonografi esnasında konuşulmamalı, her hastadan sonra etkili bir biçimde el yıkanmalı, cihazların temizliği yapılmalı, belirli aralıklarla muayene odası havalandırımalıdır $(20,21)$.

\section{Tedavi ve Yönetim}

COVID-19 enfeksiyonu şüphesi olan hastalarda uygun triaj yapılmalı, hasta sağ|ık kuruluşuna başvurusu esnasında kapıda karşılanmalı, ateş ölçümü ve klinik semptomların değerlendirilmesi gerçekleştirilmeli, şüpheli vakalar hastanede ayrılmış olan özel sahalarda muayene edimelidir. Ayrıca gebelerin başvuruda cerrahi maske takması sağlanmalı ve şüpheli vakalar ivedilikle enfeksiyon hastalıklarına konsülte edilmelidir $(3,26)$. Hastalar negatif basınçlı izole odalarda izlenmelidir. Hastanın takibi multidisipliner yaklaşımla yapılmaIıdır. Perinatoloji bölümünün de takip süreci ve olası obstetrik komplikasyonların yönetimi açısından fikri alınmalıdır. Gebelik haftasına göre fetal monito- 
rizasyonun usulüne uygun olarak sağlanmasının ve maternal vital bulguların yakın olarak takip edilmesinin önemi mevcuttur. Stabil olmayan hastalarda sürekli fetal monitorizasyon önerilirken, stabil seyreden vakalarda günde 2 kez non-stress test ile takip uygundur. Maternal oksijen saturasyonu $\geq \% 95$ 'de tutulmalıdır. Eğer saturasyon değerleri bunun altında seyrederse, arteryal kan gazı ile takip yapılmalıdır, PaO2 70 mmHg'nin üstünde tutulmalıdır. Fazla sıvı yüklemesinden kaçınılmalı, gereklilik halinde yoğun bakımda hasta takibi ve mekanik ventilasyon desteği göz önünde bulundurulmalıdır. İyileşen vakalar 2-4 haftalık aralıklarla izlenmelidir (20-26).

Hastalığın medikal tedavisi için elde bulunan seçenekler henüz kısıtlıdır. Üzerinde en çok durulan ajanlar hidroksiklorokin ve remdesivirdir. Hidroksiklorokinin in-vitro ortamda SARS-CoV-2'yi inhibe etse de tedavideki rolü ve etkinliği hala araştııımaktadır. Çok merkezli randomize kontrollü bir çalışmanın sonuçlarına göre tedavi PCR'de negatife dönme üzerinde belirgin etki göstermese de klinik semptomlarda iyileşme ile ilişkilendirilmektedir. Tedaviye bağlı yan etkilerde artışa yol açsa da ciddi yan etki görülme oranı düşük bulunmuştur(53). Hidroksiklorokin plasentayı geçmesine karşın sistemik lupus eritamatozus ve malarya gibi endikasyonlar için gebelikte kullanımında herhangi bir olumsuz etki gözlenmemiştir (54). Remdesivir SARS-CoV-2'ye karşı in-vitro ortamda etki gösteren yeni bir nükleotid analoğudur. Ebola ve Marburg virüs ile enfekte gebelerin tedavisinde belirgin fetal toksisiteye sebep olmadan kullanılmışıı (55). Tablo 2'de COVID-19 tedavisinde en sık yer alan ilaçlar ve etki mekanizmaları özetlenmiştir (56).

Tablo 2: COVID-19 tedavisinde yer alan ilaçlar ve etki mekanizmaları

\begin{tabular}{|c|c|c|c|c|c|}
\hline illaç & \begin{tabular}{|l|}
$\begin{array}{l}\text { Etki mekaniz- } \\
\text { ması }\end{array}$ \\
\end{tabular} & Doz / Uygulama & \begin{tabular}{|l|}
$\begin{array}{l}\text { Kontrendike } \\
\text { durumlar }\end{array}$ \\
\end{tabular} & Toksisite & \begin{tabular}{|l|} 
Özel \\
popülasyonlar
\end{tabular} \\
\hline $\begin{array}{l}\text { Klorokin } \\
\text { fosfat }\end{array}$ & \begin{tabular}{|l|} 
Konakçı re- \\
septörlerin \\
glikosilasyo- \\
nunu, prote- \\
olitik süreci \\
ve endozomal \\
asidifikasyonu \\
inhibe ederek \\
viral girişin \\
bloke edilmesi, \\
konakçı hüc- \\
relerde sitokin \\
üretiminin, \\
otofajinin ve \\
lizozomal akti- \\
vitenin inhibis- \\
yonu yoluyla \\
ek immünomo- \\
dülatör etki \\
\end{tabular} & $\begin{array}{l}500 \text { mg her } 12- \\
24 \text { st'te bir 5-10 } \\
\text { gün oral } \\
\text { Kreatinin kle- } \\
\text { rensi <10ml/ } \\
\text { dk ise doz } \\
\text { yarıya düşülür, } \\
\text { Karaciğer yet- } \\
\text { mezliğinde doz } \\
\text { ayarlaması öne- } \\
\text { rilmez, dikkatli } \\
\text { olunmalıdır }\end{array}$ & \begin{tabular}{|l|} 
Klorokin, \\
4-aminoki- \\
nolin türev- \\
lerine karşı \\
aşırı duyarılıık \\
varlığı. \\
Retina veya \\
görme alanı \\
değişiklikleri \\
mevcutsa \\
(yarar zarar \\
durumu \\
gözedilerek \\
verilmelidir) \\
\end{tabular} & $\begin{array}{l}\text { Sık: Abdomi- } \\
\text { nal kramp, } \\
\text { anoreksi, } \\
\text { ishal, bulant, } \\
\text { kusma } \\
\text { Majör: Kardi- } \\
\text { yovasküler et- } \\
\text { kiler (QTc uza- } \\
\text { ması dahil), } \\
\text { hematolojik } \\
\text { etkiler (G6PD } \\
\text { eksikliğinde } \\
\text { hemoliz dahil, } \\
\text { yarar zarar } \\
\text { durumuna } \\
\text { göre) hipog- } \\
\text { lisemi, retina } \\
\text { toksisitesi, } \\
\text { nöropsikiyat- } \\
\text { rik ve santral } \\
\text { sinir sistemi } \\
\text { etkileri, idi- } \\
\text { yosenkratik } \\
\text { advers ilaç } \\
\text { reaksiyonları }\end{array}$ & \begin{tabular}{|l|} 
Yarar zarar \\
durumuna \\
göre gebelikte \\
kullanılabilir
\end{tabular} \\
\hline $\begin{array}{l}\text { Hidrok- } \\
\text { siklorokin } \\
\text { sülfat }\end{array}$ & $\begin{array}{l}\text { Klorokinle aynı } \\
\text { mekanizma }\end{array}$ & $\begin{array}{l}400 \text { mg } 12 \text { st'te } \\
\text { bir } 1 \text { gün, ardın- } \\
\text { dan } 200 \text { mg } 12 \\
\text { st'te bir } 4 \text { gün } \\
\text { oral, alternatif } \\
\text { doz günlük } 400 \\
\text { mg } 5 \text { gün veya } \\
200 \text { mg günde } 3 \\
\text { kez } 10 \text { gün oral } \\
\text { Karaciğer ve } \\
\text { böbrek rahat- } \\
\text { sızlıklarında doz } \\
\text { ayarlaması öne- } \\
\text { rilmez, dikkatli } \\
\text { kullanılmalıdır } \\
\end{array}$ & \begin{tabular}{|l|} 
Hidroksiklo- \\
rokin, 4-ami- \\
nokinolin \\
türevlerine \\
karşı aşırı \\
duyarlılık \\
varlığı
\end{tabular} & \begin{tabular}{|l|} 
Klorokine \\
benzer, daha \\
nadirdir
\end{tabular} & \begin{tabular}{|l|} 
Yarar zarar \\
durumuna \\
göre gebelikte \\
kullanılabilir
\end{tabular} \\
\hline $\begin{array}{l}\text { Lopinavir } \\
\text { / ritonavir }\end{array}$ & $3 \mathrm{CL}$ proteaz & $\begin{array}{l}400 \mathrm{mg} / 100 \\
\mathrm{mg} 12 \text { st'te bir } \\
14 \text { gün, } 5 \mathrm{ml} \\
\text { oral solüsyon } \\
\text { formu etanol } \\
\text { ve propilen } \\
\text { glikol ile uyumlu } \\
\text { beslenme tüpü } \\
\text { ile verilebilir, } \\
\text { karaciğer ve } \\
\text { böbrek rahat- } \\
\text { sızlıklarında doz } \\
\text { ayarlaması öne- } \\
\text { rilmez, karaciğer } \\
\text { yetmezliğinde } \\
\text { dikkatli kullanıl- } \\
\text { malıdır } \\
\end{array}$ & $\begin{array}{l}\text { Lopinavir ve/ } \\
\text { veya rito- } \\
\text { navire karşı } \\
\text { aşırı duyarlılık } \\
\text { varlığı }\end{array}$ & $\begin{array}{l}\text { Sık: Gastroin- } \\
\text { testinal intole- } \\
\text { rans, bulant, } \\
\text { kusma, ishal. } \\
\text { Majör: } \\
\text { Pankreatit, } \\
\text { hepatotoksi- } \\
\text { site, kardiyak } \\
\text { iletim anor- } \\
\text { mallikleri }\end{array}$ & \begin{tabular}{|l|} 
Gebelikte \\
kullanılabilir \\
fakat etanol \\
içeriğinden \\
ötürü oral \\
solüsyondan \\
kaçınılmalıdır
\end{tabular} \\
\hline
\end{tabular}

\begin{tabular}{|c|c|c|c|c|c|}
\hline \begin{tabular}{|l} 
Umife- \\
novir
\end{tabular} & \begin{tabular}{|l|} 
S protein / \\
ACE2, memb- \\
ran füzyon \\
inhibitörü
\end{tabular} & $\begin{array}{l}200 \text { mg her } 8 \\
\text { st'te bir 7-14 } \\
\text { gün. } \\
\text { Böbrek rahatsı- } \\
\text { liğında doz ayar- } \\
\text { lamasına gerek } \\
\text { yoktur, karaci- } \\
\text { ğer için özel bir } \\
\text { öneri yoktur, } \\
\text { karaciğer yet- } \\
\text { meliginde dik- } \\
\text { kat edilmelidir, } \\
\text { biyoyararlanımı } \\
\% 40^{\prime} t \text { tr }\end{array}$ & \begin{tabular}{|l} 
Umifenovire \\
karşı bilinen \\
aşırı duyarlıık \\
varlığı
\end{tabular} & $\begin{array}{l}\text { Alerjik reak- } \\
\text { siyon, gast- } \\
\text { rointestinal } \\
\text { yakınmalar, } \\
\text { transaminaz- } \\
\text { larda artş }\end{array}$ & \begin{tabular}{|l|}
2 yaşından \\
küçük çocuk- \\
larda artan \\
sensitivite ne- \\
deniyle kont- \\
rendikedir
\end{tabular} \\
\hline \begin{tabular}{|l} 
Remde- \\
sivir
\end{tabular} & \begin{tabular}{|l|} 
RNA polimeraz \\
inhibitörü
\end{tabular} & \begin{tabular}{|l}
$200 \mathrm{mg} \times 1$, \\
$100 \mathrm{mg} /$ /gün IV \\
infüzyon \\
GFR<30 değilse \\
doz ayarlaması \\
önerilmez, \\
renal/hepatik \\
doz ayarlaması \\
önerilmemekle \\
birlikte toksisite \\
durumunda doz \\
azaltılması de- \\
ğerlendirilir
\end{tabular} & \begin{tabular}{|l|} 
Spesifik \\
protokollere \\
göre dişlan- \\
ma kriteri \\
varlığı duru- \\
munda
\end{tabular} & \begin{tabular}{|l|} 
Geri dönü- \\
şümlü tran- \\
saminazlarda \\
yükselme, \\
böbrek hasarı
\end{tabular} & \begin{tabular}{|l|} 
Gebelikte \\
güvenlig̈i \\
bilinmiyor, \\
şu aşamada \\
kullanımı öne- \\
rilmiyor
\end{tabular} \\
\hline Favipiravir & \begin{tabular}{|l|} 
RNA polimeraz \\
inhibitörü
\end{tabular} & 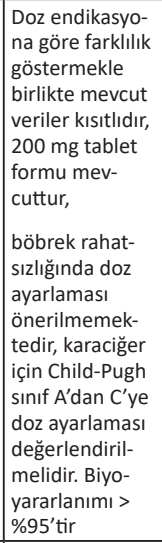 & \begin{tabular}{|l|} 
Spesifik \\
protokollere \\
göre dişlan- \\
ma kiteri \\
varlığı duru- \\
munda
\end{tabular} & $\begin{array}{l}\text { Hiperürisemi, } \\
\text { diare, tran- } \\
\text { saminazlarda } \\
\text { artş, nötrofil } \\
\text { sayısinda } \\
\text { azalma }\end{array}$ & $\begin{array}{l}\text { Gebelikte } \\
\text { kontrendike, } \\
\text { anne sütünde } \\
\text { metabolitleri } \\
\text { gösterilmiştir }\end{array}$ \\
\hline \begin{tabular}{|l|} 
Tocilizu- \\
mab
\end{tabular} & \begin{tabular}{|l|} 
IL-6 inhibis- \\
yonu, sitokin \\
firtnasında \\
azalma
\end{tabular} & 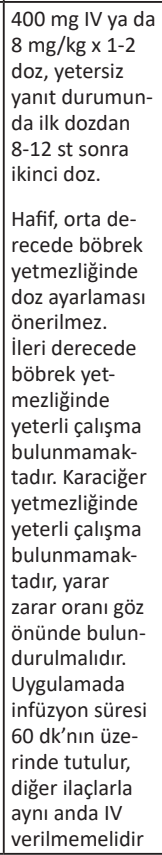 & \begin{tabular}{|l|} 
Tocilizumab \\
veya diğer \\
bilesenlere \\
karşı bilinen \\
aşııı duyarllık \\
varlı̆ı. Nöt- \\
ropeni (<500 \\
hücre/ $\mu \mathrm{L})$ \\
veya trombo- \\
sitopeni (<50 \\
$000 / \mu L)$ olan \\
hastalarda \\
dikkat edil- \\
melidir.
\end{tabular} & \begin{tabular}{|l|} 
SIk: Üst \\
solunum \\
yolu enfek- \\
siyonlarında \\
(tüberküloz \\
dahil) artş, \\
nazofarenjit, \\
başağrrsı, \\
hipertansiyon, \\
artmıs AST, in- \\
füzyonla iliskili \\
reaksiyonlar. \\
Majör: Hema- \\
tolojik etkiler, \\
enfeksiyonlar, \\
hepatotoksi- \\
site, gastroin- \\
testinal per- \\
forasyonlar, \\
aşri duyarllık \\
reaksiyonları
\end{tabular} & \begin{tabular}{|l|} 
Gebelikte \\
güvenliği bilin- \\
miyor; fetüse \\
zarar verebilir
\end{tabular} \\
\hline
\end{tabular}

Kısaltmalar: ACE2; anjiotensin-dönüştürücü enzim 2; AST; aspartat aminotransferaz; 3CL; 3-kimotripsin-benzer; GFR; glomerüler filtrasyon hızı

Sağlık Bakanlığı'nın tedavi algoritmasında oseltamivir, hidroksiklorokin, azitromisin, favipravir ve lopinavir/ritonavir gibi ilaçlar yer almaktadır. Bahsi geçen ilaçların gebelerde kullanımı konusunda çok fazla bilgi birikimi mevcut değildir. Gebelerde komplike olmayan COVID-19 enfeksiyonu varlığında öncelikle tedavisiz izlem düşünülmeli, olası tanı alan olgularda risk faktörü ya da ağır klinik seyir mevcutsa tedavi açısından değerlendirilmelidir. Gebelerde antiviral tedavinin kullanımı yönünden veriler kısıtlıdır. Lopinavir/ritonavir HIV enfeksiyonunda, oseltamivir influenzada gebe hastalarda uygulanmıştır 
ve konjenital anomaliye yol açtıklarını gösteren bir bilgi mevcut değildir. Favipravir gebelikte kontraendikedir. Hidroksiklorokin ve azitiromisinin beraber kullanımı Q-T aralığını uzatarak ölümcül aritmilere neden olabilir, bu hususta dikkatli olunmalıdır (3). Kesin tanı almış gebelerde Lopinavir $200 \mathrm{mg} /$ ritonavir $50 \mathrm{mg}$ tablet $2 \times 2$ tablet, oral, 10-14 gün ve hidroksiklorokin, $200 \mathrm{mg}$ tablet, $2 \times 400 \mathrm{mg}$ yükleme dozunu takiben, $2 \times 200 \mathrm{mg}$ tablet, oral, 5 gün süreyle uygulanabilir (3). COVID-19 kesin tanılı gebelerdeki tedavi önerileri Tablo 3'te gösterilmektedir.

Tablo 3: T.C. Sağlık Bakanlığı tarafından kesin tanılı COVID-19 enfeksiyonlu gebeler için önerilen tedavi yaklaşımı

\begin{tabular}{|l|l|l|}
\hline $\begin{array}{l}\text { Hidroksiklorokin } 200 \mathrm{mg} \text { tablet } \\
\text { veya }\end{array}$ & $2 \times 200 \mathrm{mg}$ tablet, oral & 5 gün \\
$\begin{array}{l}\text { Lopinavir 200mg / Ritonavir 50 } \\
\text { mg tablet }\end{array}$ & $2 \times 2$ tablet, oral & $10-14$ gün \\
\hline
\end{tabular}

Ayrıca son dönemde gündemde olan nötrofil ekstraselüler tuzakları (NETs) üzerinde de çalışmalar sürdürülmektedir (57). Ağır COVID-19 hastalığında görülen pnömoni ve akut respiratuar distres tablolarında artmış pulmoner inflamasyon, hava yollarının kalın mukus tıkaçları ile kapanması, artmış proinflamatuar sitokin yanıtı ve pulmoner vasküler yapıdaki mikrotrombüsler kötü prognoz ile ilişkilendirilmektedir. Bahsi geçen patolojik süreçlerden çoğunlukla abartılı bir şekilde uyarılmış olan konak immün sistem yanıtı sorumlu tutulmaktadır. Özellikle oluşan sitokin fırtınası hastayı yönetilmesi çok zor olan bir kliniğin içine çekmekte ve mortalite ile sonuçlanabilecek olaylar zincirini tetiklemektedir. Nötrofiller periferik kanda en fazla oranda bulunan beyaz küre serisidir. Ağır seyreden COVID-19 vakalarında nötrofili, artmış nötrofil/lenfosit oranı ve yoğun pulmoner nötrofil infiltrasyonu gözlenmiştir. Bu doğrultuda nötrofillerin bu aşırı immün yanıtta önemli bir rol oynayabileceği şüphesi oluşmuştur. Nötrofiller patojenleri çoğunlukla oksidatif patlama ve fagositoz yolu ile etkisiz hale getirmeye çalışmaktadır. Öte yandan NETs de patojenleri hapsetmek amacı ile kullanılan ve nötrofiller tarafından salınan ağsı yapıda DNA parçaları ve proteinleridir. Özellikle kistik fibrozis hastalığındaki mukus tıkaçlarının oluşum mekanizmasında NETs'in de yer aldığı düşünülmektedir. Yine NETs sitokin fırtınası ve akut respiratuar distres sendromu ile ilişkilendirilmektedir. Bu amaçla özellikle kistik fibrozis hastalarının tedavisinde kullanılan rekombinant DNAaz 1 (Dornoz alfa)'in NETs formasyonunun çözülmesinde ve sitokin fırtınasının azaltılmasında kullanılabileceği düşünülmektedir (57). Bu tedavinin ayrıca mukus tıkaçlarını azaltarak sekonder enfeksiyon riskini azaltabileceği ve akut respiratuar distres sendromuna ilerlemede rol oynayan bazı inflamatuar süreçleri de baskı altına alabileceği tahmin edilmektedir. Fakat bu tedavi yaklaşımı üzerinde çalışmalar henüz sürmektedir ve rutin tedavi yaklaşımları içerisinde kendisine yer bulamamıştır (57).

\section{Gebelik Komplikasyonlarını Önlemek Amacı ile} Kullanılan Medikasyonlar

Centers for Disease Control and Prevention $(C D C)$ hem influenza hastalarında mortaliteyi artırması hem de MERS-CoV enfeksiyonunda viral klirensi geciktirmesi nedeniyle fetal akciğer gelişimi için kortikosteroid uygulanması konusunda temkinli olunmasını önermektedir (58). Buna karşın ACOG antenatal kortikosteroid uygulamasının bilinen faydalarını göz önünde bulundurarak rutin obstetrik endikasyonlar dahilinde 24-336 gebelik haftası içerisinde bulunan COVID-19 enfeksiyonu ya da enfeksiyon şüphesi olan gebelerde de kullanımını önermektedir (20).

Düşük doz aspirinin preeklampsi profilaksisinde kullanımı için bireyselleştirilmiş yaklaşım önerilmektedir. Her ne kadar ibuprofen kullanımının hastalığın şiddetini arttırabileceği yönünde şüpheler olsa da düşük doz aspirin kullanımının güvenli olduğu düşünülmektedir (20).

Tokoliz amacıyla ilk tercih olarak nifedipin önerilmektedir. Nonsteroid yapıda olan ibuprofen ve maternal kalp atımını artıran betamimetikler mümkün mertebede tercih edilmemektedir. Eklampsi profilaksisi ve neonatal nöroproteksiyon amacıyla magnezyum sülfat uygulanırken olası solunum depresyonu riskine karşı dikkatli olunmalı, uygulama öncesinde göğüs hastalıkları ve perinatoloji bölümleri ile konsültasyon sağlanmalıdır (20-26)

\section{İntrapartum Yönetim}

Hafif vakalarda doğum zamanlamasını erkene çekmek önerilmemektedir. Ayrıca hastanın PCR testinin negatifleştiği dönemde doğumun gerçekleşmesi olası neonatal bulaşı önleyebilir. Buna karşın ağır vakalarda 32. gestasyonel haftadan sonra doğum kararı gözden geçirilebilir (20-26).

Şüpheli vakalar ile ilgilenecek sağlık personeli el hijyenine ve kişisel koruyucu ekipman kullanımına dikkat etmeli, eldiven, izolasyon önlüğü, gözlük/ yüz koruyucu, tıbbi maske kullanımı sağlanmalıdır. Özellikle entübasyon gibi hastanın solunum sekresyonlarının saçılımına sebep olabilecek işlemleri gerçekleştirecek sağlık personeli mevcut ekipmanlara ek olarak N95/FFP2 maske ve yüz koruyucu da kullanmalıdır. Kişisel koruyucu ekipmanların çıkartılmasında da yine Sağılı Bakanlığı ve uluslararası cemiyetler tarafından önerilen uygulamalara dikkat edilmelidir (20-26).

Doğumun şekli obstetrik endikasyonlar doğrultusunda seçilmelidir. Doğum negatif basınçlı izole odalarda gerçekleştirilmelidir. Maternal vital bulgular yakın olarak izlenmeli, sürekli fetal monitorizasyon sağlanmalıdır. Maternal oksijen saturasyonu $\geq \% 95$ olarak tutulmalıdır. Kişisel koruyucu ekipman kullanımına dikkat edilmeli, sezaryen doğumlarda ve vajinal doğumun ikinci evresinde N95/FFP2 maske ve yüz koruyucu ekipman kullanılmalıdır. Rejyonel anestezi gerek bulaş riski, gerek maternal komplikasyonlar açısından daha avantajlı bir yaklaşım olarak görülmektedir. Nitröz oksit sistemlerinin temizlik, filtre ve havalanma gibi konularında net bir standart bulunmadığı için, nitröz oksit kullanımı konusunda temkinli olunmalıdır. Ayrıca solunum depresyonu riski mevcut olduğundan kişisel kontrollü analjezik uygulamalarından kaçınılmalıdır (20-26). Vajinal sekresyonlarda ve amniyon mayisinde virüs izole edilemediğinden amniyotomi ve fetal monitorizasyon gibi işlemlerde bulaş riskinin bulunmadığı düşünülmektedir. Öte yandan maternal ıkınma esnasında dışarı çıkan feçes ile teorik olarak bulaş riski mevcuttur. Erken ya da geç kord klemplenmesinin bilinen bir etkisi yoktur ve endike vakalarda kordon kanı toplanmasının güvenli olduğu yönünde görüş mevcuttur. Ten tene temastan bulaş riski açısından kaçınılabilir (20-26)

\section{Akut hastalığı olan gebenin takibi}

Eğer bir gebede saturasyon düşüklüğü mevcutsa, etyopatolojide enfektif (COVID-19 olan veya olmayan pnömoni), inflamatuar (sistemik inflamatuar yanıt sendromu), kardiyojenik (peripartum kardiyomiyopati, viral miyokardit) ve kardiyojenik olmayan pulmoner ödem (hipertansif ve hipertansif olmayan pulmoner ödem) gibi birden fazla faktör rol alabilmektedir. Bu nedenle akut hastalığı olan travaydaki gebenin yönetiminde dikkat edilmesi gereken durumlar aşağıda listelenmiştir (59)

1-Eğer travaydaki bir gebede maternal ve/veya fetal durumda bir bozulma mevcutsa acil sezaryen düşünülmeli, maternal oksijen satürasyonu (Sp02) $>\% 93$ ise rejyonel anestezi, $<\% 93$ ise genel anestezi planlanmalıdır.

2-Maternal ve/veya fetal durumda herhangi bir bozulma yok, hemodinami stabil ve maternal SpO2>\%93 ise erken epidural anestezi ile vajinal doğum değerlendirilmelidir.

3- Maternal ve/veya fetal durumda herhangi bir bozulma yok, maternal SpO2>\%93, anne hipertansifse preeklampsi protokolü uygulanmalıdır.

4- Maternal ve/veya fetal durumda herhangi bir bozulma yok, maternal SpO2>\%93 fakat anne hipotansifse bu durumda yoğun bakım gereksinimi açısından hasta değerlendirilmeli gerekirse ekokardiyografi yapılmalıdır. Ekokardiyografide kardiyak boşluklar dilate görümdeyse, sistemik vasküler rezistansın normal (SVR) ve kardiyak outputun (KO) azalması nedeniyle öncelikle kardiyojenik şok düşünülmeli, sıvı kısıtlaması yapılmalı, inotropik tedaviler planlanmalıdır. Fakat mevcut tedaviye rağmen sağ ventrikül dilatasyonu varsa ayıııcı tanıda amniyon sıvı embolisi ve pulmoner emboli düşünülmelidir.

5- Eğer ekokardiyografide hiperdinamik bir sol ventrikül görümü mevcutsa, sistemik vasküler rezistansın azalması (SVR) ve kardiyak outputun (KO) artması nedeniyle öncelikle septik şok düşünülmeli, sıvı resüsitasyonu yapılmaII, vazopresör tedaviler planlanmalıdır.

6- Ekokardiyografi normalse sıvı tedavisi yönünden dikkatli olunmalı, inotropik veya vazopresör tedaviler düşünülmelidir. Fakat tedaviye rağmen tablo ağırlaşıyorsa akut respiratuvar distress sendromu (ARDS) ve refrakter hipoksemi yönünden dikkat edilmeli gerekirse ekstrakorporal membran oksijenizasyonu (ECMO) yönünden hasta değerlendirilmelidir.

\section{Postpartum Bakım}

COVID-19 olduğundan şüphelenilen ve test sonuçları bilinmeyen annelerin (beklemede veya test edilmemiş) yenidoğanları CDC tarafından şüpheli görülmemektedir. Buna karşın bilinen COVID-19 enfeksiyonu olan annelerin yenidoğanları enfeksiyon açısından hemen test edilmeli, diğer yenidoğanlardan izole edilmeli ve bulaş açısından gerekli önlemler alınmalıdır (58). Her ne kadar COVID-19 hastalığı olan gebelerin anneden bebeğe bulaş riskini azaltmak amacıyla izole edilmesi önerilse de bu durum anne-çocuk bağlanması, emzirmenin sürdürülmesi ve güvenli bağlanma açısından olumsuz sonuçlar doğurabilir (20-26). Bu durumda emzirme kararı multidisipliner bir ekip tarafından fayda zarar beklentisi doğrultusunda verilmelidir. Emzirme durumunda el hijyenine dikkat edilmeli, bebek beslenirken maske takılmalı, pompa kulla- 
nılıyorsa her kullanımdan sonra uygun şekilde temizlenmeli ve her aşamada süt sterilizasyon kurallarına uyularak verilmelidir (20-26).

Bir başka önemli nokta da hastalarda iyileşme kriteri olarak kullanılan PCR testindeki negatifliklerin hasta taburcu edildikten bir süre sonra pozitifleşebileceğidir. Çin'de yapılmış olan bir çalışmanın sonuçlarına göre taburcu edilmiş olan 172 hastadan $25^{\prime}$ inde (\%14.5) kontrol PCR sonuçları pozitif olarak gelmiştir (60). Bu açıdan hastaların taburculuk sonrası izolasyonu sağlanmalı, hastalar ile sağık ekibi arasındaki iletişim devam ettirilmeli, şüpheli vakalarda test tekrarlanmalıdır.

\section{Aşı Çalışmaları}

Maalesef COViD-19 enfeksiyonu için etkinliği kanıtlanmış bir aşı henüz mevcut değildir. Buna karşın aşı geliştirmek amacı ile yürütülen klinik çalışmalar mevcuttur (61). Çalışmaların büyük kısmı S proteini kodlayan sekansı (virüsün dikensi çıkıntılarını kodlayan bölüm) hedefleyen nükleik asit bazlı aşı modelleri üzerindedir (61). Prefüzyon-stabilize edilmiş viral dikensi proteinin m-RNA'sının sentetik bir ipliğini içeren m-RNA-1273 Faz 1 çalışmasını geçmiştir ve üretimi için canlı virüse gereklilik duyulmaması nedeniyle güvenli kabul edilmektedir (62). Öte yandan bir DNA aşısı olan INO-4800 de ümit vaat etmektedir. Bu insan hücrelerine taşınıp immün yanıt meydana getirebilme potansiyeline sahip genetik bir aşıdır $(61,62)$. SARS-CoV-2'nin s proteini ve replike olmayan bir adenovirüs vektörünü içeren ChAdOx1 nCoV-19 da Faz 1-2 aşamasında denenmektedir. İçerisindeki adenovirüs vektörün özelliği nedeniyle pediatrik grupta ve altta yatan hastalığı olanlarda güvenli olma potansiyeline sahiptir(61, 62). Ayrıca ACE-2 reseptörünü en çok eksprese eden solunum ve gastrointestinal epiteli hedef almaktadır. Diğer taraftan virüsün pre-füzyon glikopoteinlerini hedef alan stabilize edilmiş virüs altgruplarından oluşan aşılar üzerine de çalışmalar mevcuttur. Benzer yapıdaki aşılar influenza ve Ebola virüslerine karşı uygulanmış ve nötralize edici antikor üretimini uyarmayı başarmıştır $(61,62)$. Ayrıca nanopartiküllerin antijenik epitoplar ile konjüge edilmesi yoluyla aşı elde etme çalışmaları da mevcuttur. Son olarak patojene spesifik artifisyel antijen sunan hücreler üzerine de çalışmalar yapılmaktadır $(61,62)$.

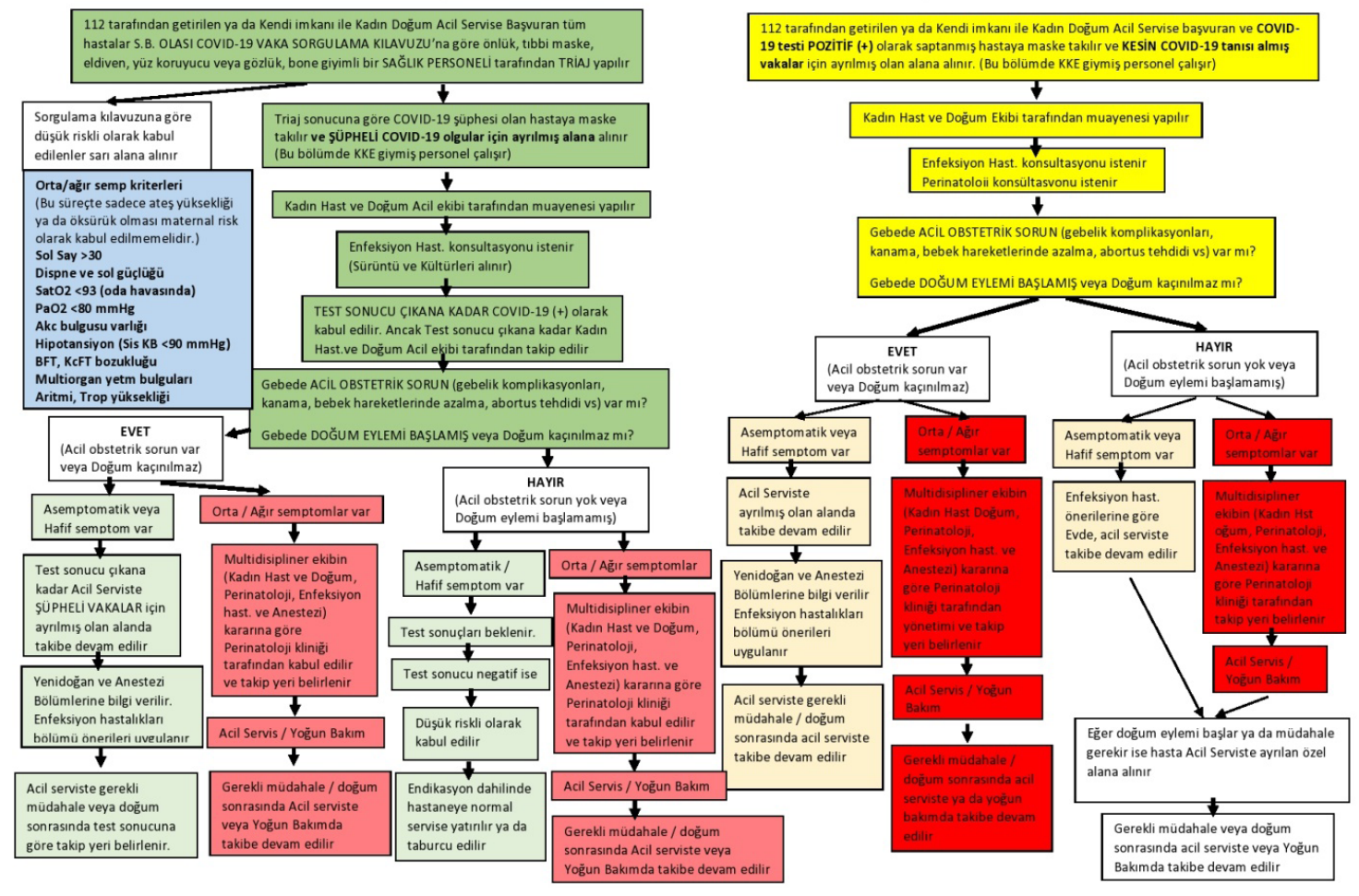

\section{SONUÇ}

COVID-19 enfeksiyonu henüz kontrol altına alınamamış bir salgındır ve patojen olan virüs üzerindeki bilgi birikimimiz şu an için kısıtıdır. Öte yandan tanı, tedavi ve enfeksiyonun yönetimi üzerinde umut vaat den çalışmalar sürdürülmektedir. Gebeler her konuda olduğu gibi COVID-19 enfeksiyonunda da özellikli bir grup olarak kabul edilmekte ve gebelerin bu süreçteki yönetimi çeşitli farklııklar içermektedir. Gebe popülasyona hizmet sunan sağlık çalışanları güncel literatürü yakından takip etmeli, spesifik komplikasyonların yönetimi konusunda yetkin olmalı, anne/bebek sağlığını korumayı birincil hedef olarak belirlemeli ve bu süreçte kişisel güvenliğini de sağlamalıdır. Ayrıca multidisipliner bir ekip içerisinde uyumla çalışmalı, hastalara maksimum faydayı sağlamalıdır.

\section{REFERANSLAR}

1. Novel Coronavirus (2019-nCoV) technical guidance 2020 [Available from: https://www.who.int/emergencies/diseases/novel-coronavirus-2019/technical-guidance

2. Guan Wei-jie, Ni Zheng-yi, Hu Yu, Liang Wen-hua, Ou Chun-quan, He Jian-xing, et al. Clinical characteristics of coronavirus disease 2019 in China. New England Journal of Medicine. 2020.

3. COVID-19 (SARS-CoV-2 Enfeksiyonu) Rehberi 2020 [Available from: httJinekoloji - Obstetrik ve Neonatoloji Tip Dergisi 2020; Volume 17, Sayı 2,Sayfa: 378-387
ps://covid19bilgi.saglik.gov.tr/depo/rehberler/COVID-19_Rehberi.pdf.

4. Zhou P., Yang X. L., Wang X. G., Hu B., Zhang L., Zhang W., et al. A pneumonia outbreak associated with a new coronavirus of probable bat origin. Nature. 2020;579(7798):270-3.

5. van Doremalen N., Bushmaker T., Morris D. H., Holbrook M. G., Gamble A., Williamson B. N., et al. Aerosol and Surface Stability of SARS-CoV-2 as Compared with SARS-CoV-1. The New England journal of medicine. 2020.

6. Chen W., Lan Y., Yuan X., Deng X., Li Y., Cai X., et al. Detectable 2019$n C o V$ viral RNA in blood is a strong indicator for the further clinical severity. Emerging microbes \& infections. 2020;9(1):469-73.

7. Wang W., Xu Y., Gao R., Lu R., Han K., Wu G., et al. Detection of SARSCoV-2 in Different Types of Clinical Specimens. Jama. 2020.

8. Dhama Kuldeep, Sharun Khan, Tiwari Ruchi, Sircar Shubhankar, Bhat Sudipta, Malik Yashpal Singh, et al. Coronavirus Disease 2019-COVID-19. 2020.

9. Wu Z., McGoogan J. M. Characteristics of and Important Lessons From the Coronavirus Disease 2019 (COVID-19) Outbreak in China: Summary of a Report of 72314 Cases From the Chinese Center for Disease Control and Prevention. Jama. 2020.

10. Wang D., Hu B., Hu C., Zhu F., Liu X., Zhang J., et al. Clinical Charac- 
teristics of 138 Hospitalized Patients With 2019 Novel Coronavirus-Infected Pneumonia in Wuhan, China. Jama. 2020.

11. Huang C., Wang Y., Li X., Ren L., Zhao J., Hu Y., et al. Clinical features of patients infected with 2019 novel coronavirus in Wuhan, China. Lancet (London, England). 2020;395(10223):497-506.

12.Zhao W., Zhong Z., Xie X., Yu Q., Liu J. Relation Between Chest CT Findings and Clinical Conditions of Coronavirus Disease (COVID-19) Pneumonia: A Multicenter Study. AJR American journal of roentgenology. 2020:1-6.

13.Zhao J., Yuan Q., Wang H., Liu W., Liao X., Su Y., et al. Antibody responses to SARS-CoV-2 in patients of novel coronavirus disease 2019. Clinical infectious diseases : an official publication of the Infectious Diseases Society of America. 2020.

14.Liu D., Li L., Wu X., Zheng D., Wang J., Yang L., et al. Pregnancy and Perinatal Outcomes of Women With Coronavirus Disease (COVID-19) Pneumonia: A Preliminary Analysis. AJR American journal of roentgenology. 2020:1-6. 15.Breslin Noelle, Baptiste Caitlin, Gyamfi-Bannerman Cynthia, Miller Russell, Martinez Rebecca, Bernstein Kyra, et al. COVID-19 infection among asymptomatic and symptomatic pregnant women: Two weeks of confirmed presentations to an affiliated pair of New York City hospitals.

16.COVID CDC. Preliminary Estimates of the Prevalence of Selected Underlying Health Conditions Among Patients with Coronavirus Disease 2019-United States, February 12-March 28, 2020. 2020.

17.Mullins E., Evans D., Viner R. M., O'Brien P., Morris E. Coronavirus in pregnancy and delivery: rapid review. Ultrasound in obstetrics \& gynecology : the official journal of the International Society of Ultrasound in Obstetrics and Gynecology. 2020.

18.Liu H., Wang L. L., Zhao S. J., Kwak-Kim J., Mor G., Liao A. H. Why are pregnant women susceptible to COVID-19? An immunological viewpoint. J Reprod Immunol. 2020;139:103122.

19.Qiao Jie. What are the risks of COVID-19 infection in pregnant women? The Lancet. 2020;395(10226):760-2.

20.Obstetricians American College of, Gynecologists. Practice Advisory: Novel Coronavirus 2019 (COVID-19). 2020.

21.Boelig Rupsa C, Saccone Gabriele, Bellussi Federica, Berghella Vincenzo. MFM Guidance for COVID-19. American Journal of Obstetrics \& Gynecology MFM. 2020:100106.

22.Francesca Donders MD, Lonnee-Hoffmann Risa, Mendling MD, de Oliveira José Martinez, Judlin Philippe, Fengxia Xue, et al. ISIDOG recommendations concerning COVID-19 and pregnancy.

23.Coronavirus (COVID-19) infection and pregnancy Version 72020 [updated 09/04/2020. Available from: $h$ ttps://www.rcog.org.uk/coronavirus-pregnancy.

24.Poon Liona C, Yang Huixia, Lee Jill CS, Copel Joshua A, Leung Tak Yeung, Zhang Yuanzhen, et al. ISUOG Interim Guidance on 2019 novel coronavirus infection during pregnancy and puerperium: information for healthcare professionals. Ultrasound in Obstetrics \& Gynecology. 2020.

25.Poon Liona C, Shennan Andrew, Hyett Jonathan A, Kapur Anil, Hadar Eran, Divakar Hema, et al. The International Federation of Gynecology and Obstetrics (FIGO) initiative on pre-eclampsia: A pragmatic guide for first-trimester screening and prevention. International journal of gynaecology and obstetrics: the official organ of the International Federation of Gynaecology and Obstetrics. 2019;145:1.

26.Gebelikte Coronavirüs Enfeksiyonu (COVID-19) Hakkında Görüş (3. Bilgilendirme,03.04.2020) Türkiye2020 [Available from: http://www.tmftp.org/tr/ covid-19-detay/3-bilgilendirme-icin-tiklayin.

27.Zaigham M, Andersson O. Maternal and Perinatal Outcomes with COVID-19: a systematic review of 108 pregnancies. Acta obstetricia et gynecologica Scandinavica. 2020.

28.Karami P., Naghavi M., Feyzi A., Aghamohammadi M., Novin M. S., Mobaien A., et al. Mortality of a pregnant patient diagnosed with COVID-19: A case report with clinical, radiological, and histopathological findings. Travel Med Infect Dis. 2020:101665.

29.Chen Huijun, Guo Juanjuan, Wang Chen, Luo Fan, Yu Xuechen, Zhang Wei, et al. Clinical characteristics and intrauterine vertical transmission potential of COVID-19 infection in nine pregnant women: a retrospective review of medical records. The Lancet. 2020;395(10226):809-15.

30.Chen Siyu, Liao E, Shao Yong. Clinical analysis of pregnant women with 2019 novel coronavirus pneumonia. Journal of Medical Virology. 2020.

31.Li Yang, Zhao Ruihong, Zheng Shufa, Chen Xu, Wang Jinxi, Sheng Xiaoli, et al. Early Release-Lack of Vertical Transmission of Severe Acute Respira- tory Syndrome Coronavirus 2, China. 2020.

32.Fan Cuifang, Lei Di, Fang Congcong, Li Chunyan, Wang Ming, Liu Yuling, et al. Perinatal Transmission of COVID-19 Associated SARS-CoV-2: Should We Worry? Clinical Infectious Diseases. 2020.

33.Zhu Huaping, Wang Lin, Fang Chengzhi, Peng Sicong, Zhang Lianhong, Chang Guiping, et al. Clinical analysis of 10 neonates born to mothers with 2019-nCoV pneumonia. Translational pediatrics. 2020;9(1):51.

34.Zambrano Lysien I, Fuentes-Barahona Itzel Carolina, Bejarano-Torres Daysi Anabell, Bustillo Carolina, Gonzales Gloria, Vallecillo-Chinchilla Gissela, et al. A pregnant woman with COVID-19 in Central America. Travel Med Infect Dis. 2020;101639.

35.Gidlöf Sebastian, Savchenko Julia, Brune Thomas, Josefsson Hampus. COVID-19 in pregnancy with comorbidities: More liberal testing strategy is needed. Acta obstetricia et gynecologica Scandinavica. 2020.

36.Yu Nan, Li Wei, Kang Qingling, Xiong Zhi, Wang Shaoshuai, Lin Xingguang, et al. Clinical features and obstetric and neonatal outcomes of pregnant patients with COVID-19 in Wuhan, China: a retrospective, single-centre, descriptive study. The Lancet Infectious Diseases. 2020.

37.Breslin Noelle, Baptiste Caitlin, Miller Russell, Fuchs Karin, Goffman Dena, Gyamfi-Bannerman Cynthia, et al. COVID-19 in pregnancy: early lessons. American Journal of Obstetrics \& Gynecology MFM. 2020:100111.

38. Iqbal Sara N, Overcash Rachael, Mokhtari Neggin, Saeed Haleema, Gold Stacey, Auguste Tamika, et al. An Uncomplicated Delivery in a Patient with Covid-19 in the United States. New England Journal of Medicine. 2020.

39.Lee DH, Lee J, Kim E, Woo K, Park HY, An J. Emergency cesarean section on severe acute respiratory syndrome coronavirus 2 (SARS-CoV-2) confirmed patient. Korean journal of anesthesiology. 2020.

40.Ferrazzi E. M., Frigerio L., Cetin I., Vergani P., Spinillo A., Prefumo F., et al. COVID-19 Obstetrics Task Force, Lombardy, Italy: executive management summary and short report of outcome. International journal of gynaecology and obstetrics: the official organ of the International Federation of Gynaecology and Obstetrics. 2020.

41.Wu X., Sun R., Chen J., Xie Y., Zhang S., Wang X. Radiological findings and clinical characteristics of pregnant women with COVID-19 pneumonia. International journal of gynaecology and obstetrics: the official organ of the International Federation of Gynaecology and Obstetrics. 2020.

42.Xiong X., Wei H., Zhang Z., Chang J., Ma X., Gao X., et al. Vaginal Delivery Report of a Healthy Neonate Born to a Convalescent Mother with COVID-19. J Med Virol. 2020.

43.Khan S., Jun L., Nawsherwan, Siddique R., Li Y., Han G., et al. Association of COVID-19 infection with pregnancy outcomes in healthcare workers and general women. Clinical microbiology and infection : the official publication of the European Society of Clinical Microbiology and Infectious Diseases. 2020. 44.Kerr Stephen M, Parker Samantha E, Mitchell Allen A, Tinker Sarah C, Werler Martha M. Periconceptional maternal fever, folic acid intake, and the risk for neural tube defects. Annals of epidemiology. 2017;27(12):777-82. e1. 45.Schwartz D. A. An Analysis of 38 Pregnant Women with COVID-19, Their Newborn Infants, and Maternal-Fetal Transmission of SARS-CoV-2: Maternal Coronavirus Infections and Pregnancy Outcomes. Archives of pathology \& laboratory medicine. 2020.

46.Di Mascio Daniele, Khalil Asma, Saccone Gabriele, Rizzo Giuseppe, Buca Danilo, Liberati Marco, et al. Outcome of Coronavirus spectrum infections (SARS, MERS, COVID 1-19) during pregnancy: a systematic review and meta-analysis. American Journal of Obstetrics \& Gynecology MFM. 2020:100107

47.Dong L., Tian J., He S., Zhu C., Wang J., Liu C., et al. Possible Vertical Transmission of SARS-CoV-2 From an Infected Mother to Her Newborn. Jama. 2020.

48.Zeng L., Xia S., Yuan W., Yan K., Xiao F., Shao J., et al. Neonatal Early-Onset Infection With SARS-CoV-2 in 33 Neonates Born to Mothers With COVID-19 in Wuhan, China. JAMA Pediatr. 2020.

49.Zeng H., Xu C., Fan J., Tang Y., Deng Q., Zhang W., et al. Antibodies in Infants Born to Mothers With COVID-19 Pneumonia. Jama. 2020.

50.Kimberlin D. W., Stagno S. Can SARS-CoV-2 Infection Be Acquired In Utero?: More Definitive Evidence Is Needed. Jama. 2020.

51.Tremblay Emilie, Thérasse Eric, Thomassin-Naggara Isabelle, Trop Isabelle. Quality initiatives: guidelines for use of medical imaging during pregnancy and lactation. Radiographics. 2012;32(3):897-911.

52.Moro F., Buonsenso D., Moruzzi M. C., Inchingolo R., Smargiassi A., Demi 
L., et al. How to perform lung ultrasound in pregnant women with suspected COVID-19 infection. Ultrasound in obstetrics \& gynecology : the official journal of the International Society of Ultrasound in Obstetrics and Gynecology. 2020.

53.Tang Wei, Cao Zhujun, Han Mingfeng, Wang Zhengyan, Chen Junwen, Sun Wenjin, et al. Hydroxychloroquine in patients with COVID-19: an open-label, randomized, controlled trial. medRxiv. 2020:2020.04.10.20060558.

54.Parke Ann. Antimalarial drugs and pregnancy. The American journal of medicine. 1988;85(4):30-3.

55.Mulangu S., Dodd L. E., Davey R. T., Jr., Tshiani Mbaya O., Proschan M., Mukadi D., et al. A Randomized, Controlled Trial of Ebola Virus Disease Therapeutics. The New England journal of medicine. 2019;381(24):2293-303. 56.Sanders James M, Monogue Marguerite L, Jodlowski Tomasz Z, Cutrell James B. Pharmacologic Treatments for Coronavirus Disease 2019 (COVID-19): A Review. JAMA. 2020.

57.Barnes B. J., Adrover J. M., Baxter-Stoltzfus A., Borczuk A., Cools-Lartigue J., Crawford J. M., et al. Targeting potential drivers of COVID-19: Neutrophil extracellular traps. The Journal of experimental medicine. 2020;217(6). 58.Rasmussen Sonja A, Smulian John C, Lednicky John A, Wen Tony S, Jamieson Denise J. Coronavirus Disease 2019 (COVID-19) and Pregnancy:
What obstetricians need to know. American journal of obstetrics and gynecology. 2020.

59.Ashokka Balakrishnan, Loh May-Han, Tan Cher Heng, SU Lin Lin, Young Barnaby Edward, Lye David Chien, et al. Care of the Pregnant Woman with COVID-19 in Labor and Delivery: Anesthesia, Emergency cesarean delivery, Differential diagnosis in the acutely ill parturient, Care of the newborn, and Protection of the healthcare personnel. American Journal of Obstetrics and Gynecology. 2020.

60.Yuan Jing, Kou Shanglong, Liang Yanhua, Zeng JianFeng, Pan Yanchao, Liu Lei. PCR Assays Turned Positive in 25 Discharged COVID-19 Patients. Clinical Infectious Diseases. 2020.

61.Tu Yung-Fang, Chien Chian-Shiu, Yarmishyn Aliaksandr A, Lin Yi-Ying, Luo Yung-Hung, Lin Yi-Tsung, et al. A Review of SARS-CoV-2 and the Ongoing Clinical Trials. International Journal of Molecular Sciences. 2020;21(7):2657.

62.Shi Y, Wang N, Zou QM. Progress and challenge of vaccine development against 2019 novel coronavirus (2019-nCoV). Zhonghua yu Fang yi xue za zhi [Chinese Journal of Preventive Medicine]. 2020;54:E029-E. 